\title{
The importance of soils in predicting the future of plant habitat suitability in a tropical forest
}

\author{
G. Zuquim (D) F. R. C. Costa • H. Tuomisto • \\ G. M. Moulatlet $\cdot$ F. O. G. Figueiredo
}

Received: 23 July 2018 / Accepted: 11 December 2018/Published online: 17Ja nuary 2019

(C) The Author(s) 2019

\begin{abstract}
Aims Assessment of the future of biodiversity under climate change has been based on climate-only models. We investigated the effects of including soil information when predicting future suitable areas for selected plant species in Amazonia.

Methods We modelled current and future suitable habitats for 35 plant species and compared results of climate-only models with those obtained when climatic and edaphic variables were included. We considered six climatic scenarios for 2050 using different algorithms and projections of atmospheric $\mathrm{CO}_{2}$ concentration.

Results Twenty-five species distribution models had an AUC $>0.69$. Out of those, edaphic variables had the
\end{abstract}

Responsible Editor: Rafael S. Oliveira.

Electronic supplementary material The online version of this article (https://doi.org/10.1007/s11104-018-03915-9) contains supplementary material, which is available to authorized users.

G. Zuquim $(\bowtie) \cdot H$. Tuomisto

Department of Biology, University of Turku, Finland, FI-20014, Turun Yliopisto, Turku, Finland

e-mail: gabriela.zuquim@utu.fi

F. R. C. Costa · F. O. G. Figueiredo

Coordination of Biodiversity Research, National Institute of Amazonian Research, Av. André Araújo, 2936 - Petrópolis, Manaus, AM 69067-375, Brazil

G. M. Moulatlet

Universidad Regional Amazónica - Ikiam, Vía Tena, Muyuna Kilómetro 7, Tena, Ecuador greatest contribution in 11 species models, while climatic variables were more important for 14 species. The inclusion of soil variables affected the size and shape of predicted suitable areas, especially in future models. For nearly half of the species, the size of future suitable areas were smaller in climate+soil models than predicted by climate-only models. Area reduction was more extreme in future scenarios with the higher level of $\mathrm{CO}_{2}$ concentration.

Conclusions Our results highlight the importance of moving beyond climatic scenarios when modelling biodiversity responses to climate change. Failure to include soils in the models can overestimate future habitat suitability for many plant species.

Keywords Climate change $\cdot$ Species distribution modelling $\cdot$ Amazonia $\cdot$ Soil base cation concentration
Abbreviations
GBIF Global biodiversity information facility
IDigiBio Integrated digitized biocollections
CMIP5 Coupled model intercomparison project phase 5
RCP Representative concentration pathways
PPBio Brazilian research program on biodiversity
RADAM Amazonian radar project
BAU Business-as-usual
GOV Governance
CEC Cation exchangeable capacity
AUC Area under the curve
AIC Akaike information criterion 


\section{Introduction}

Climate, soil and dispersal capacity are the main natural determinants of current plant species distributions across the globe. Recent changes in climatic conditions are already affecting diversity patterns and ecosystem functioning, highlighting the pressure for species migration to meet their climatic niche requirements (Walther et al. 2002; Parmesan and Yohe 2003; Dillon et al. 2010; Pecl et al. 2017). Such effects are expected to increase during this century (Thomas et al. 2004) which reinforces the need for a research agenda focused on future biodiversity scenarios (Bellard et al. 2012; Lenoir and Svenning 2015; Poloczanska et al. 2013; Gruner et al. 2017).

Amazonia harbors the largest remaining area of tropical forest in the world and provides important ecosystem services that are heavily threatened by anthropogenic activities, particularly deforestation and global warming (Herraiz et al. 2017). Climate change scenarios predict drier and warmer future conditions for much of the Amazon region (Boisier et al. 2015; Cox et al. 2013; Spracklen et al. 2012) and drought-related fires have already become more frequent (Aragão et al. 2018). Climate projections for tropical areas have predicted a general increase in climate anomalies such as El Niño y La Niña events (Marengo and Espinoza 2016), rise of temperatures by up to $8^{\circ} \mathrm{C}$ over the twenty-first century (Betts et al. 2008) and enhanced drought periods (Malhi et al. 2008). The drier and hotter future climate predicted for Amazonia (Betts et al. 2008) could drive a contraction in many species ranges, given that Amazonian plant species tend to be adapted to moist rainforest conditions and, hence, are sensitive to drought (Esquivel-Muelbert et al. 2017a, b; Nepstad et al. 2007).

In theory, the biological response to climate change can be either that i) species shift their distributions and migrate to suitable climate conditions (Feeley et al. $2011 \mathrm{a}, \mathrm{b}$ ), ii) species perish because they cannot tolerate the new climatic conditions and are unable to migrate or iii) species have sufficient phenotypic plasticity to cope with the climate change (Bush et al. 2016). Estimates of climatic tolerances of species and populations are difficult to determine, as well as migration and evolutionary rates. Nonetheless, ecological niche models predict that many species are to experience severe habitat loss and possible extinction (Miles et al. 2004) and the future of a species greatly depends on its abilities to thermal adaptation and migration (Feeley et al. 2012). Moreover, long-term inventories showed that dry-affiliated tree genera are becoming more common in Amazonia, even though recruitment rates are probably slower than the trends in climate change (EsquivelMuelbert et al. 2018).

Assessment of the future of global biodiversity using ecological niche modelling have proved to be an useful and intuitive framework. However, potential effects of climate change on species distribution has, so far, been based mainly on climate-only models (Bellard et al. 2012). Given that the effects of climate change on forest structure and species survival can vary along topoedaphic gradients (Levine et al. 2016), species migration may be constrained by soil suitability in their potential migration pathway. Soils may filter species establishment through nutrient availability (Cámara-Leret et al. 2017; Tuomisto et al. 2016; Zuquim et al. 2012), water retention properties (Schietti et al. 2014), root-limiting physical conditions (Emilio et al. 2014), and biotic interactions conditioned by soil properties (Fine et al. 2004; Bever et al. 2010). If soils are not suitable for the species, the area is outside its niche tolerance and with low probability of its occurrence, regardless of climatic conditions. Therefore, climate-only ecological niche models are conceptually weak (Velazco et al. 2017) and their respective spatial predictions may be unreliable.

Investigating the future spatial distribution of niches that are analogous to current niche occupied by species is determinant to biodiversity conservation in the midterm. To achieve reliable models, environmental preferences of the species should be properly represented. It is well documented that Amazonian forests vary considerably in soil and hydrology conditions as well as in species composition and vegetation structure (Tuomisto et al. 2003; Quesada et al. 2010; Higgins et al. 2011; Zuquim et al. 2012; Baldeck et al. 2016). Most plant species distributions in Amazonia that have been studied in detail have been found to be strongly affected by soil characteristics (Gentry 1988; Tuomisto and Poulsen 1996; Figueiredo et al. 2018). Therefore, models aiming to predict future habitat suitability should include soil conditions as well as climate.

One also needs caution when modelling future species suitable areas that large differences exist among predictions of future climatic conditions. To incorporate uncertainties and provide not one, but several climatic scenarios, 20 modelling groups promoted a set of coordinated climate model experiments known as Coupled Model Intercomparison Project phase 5 (CMIP5). The ensembled 
climatologies differ in their input algorithms and in the assumptions about if and when the atmospheric $\mathrm{CO}_{2}$ concentration peaks and starts to decline. The $\mathrm{CO}_{2}$ emission scenarios considered a wide range of possibilities in future anthropogenic greenhouse gas emissions, reflecting the climatic policies adopted, if any (Moss et al. 2010; van Vuuren et al. 2011a).

The impact of other factors than climate on plant dispersal to and establishment in environmentally suitable areas may increase the negative climate effect of global warming on biodiversity. We thus aimed to understand to what degree taking soils into account affects the modelled availability of habitats for selected plant species given several scenarios of future climatic conditions in Amazonia.

\section{Methods}

\section{Plant data}

We compiled occurrence data for 35 species of herbs, lianas, trees and palms from biodiversity platforms (Global Biodiversity Information Facility - GBIF; Integrated Digitized Biocollections - IDigiBio); herbaria located in Brazil (INPA, IAN and MG) and USA (NY and $\mathrm{MBG}$ ), and from plot-based inventories (Brazilian Research Program on Biodiversity - PPBio and RADAM-Brasil). Pre-modelling procedures consisted of removing geographical outliers and duplicated records, and reducing spatial bias (as described in Figueiredo et al. 2018). The 35 species were selected to cover a broad variability in plant size, life history strategies and phylogeny. We targeted species that are easy to identify in the field to avoid taxonomical errors. The list of the selected species is presented in Figueiredo et al. (2018 - Table 1), except that we left out all fern species. Exclusion of fern species was done to avoid circularity, given that the same fern records were used to develop the map of soil base cation concentration used for modelling (see next section). We also excluded Eperua falcata, whose GBIF records contained misidentified Eperua leucantha (ter Steege, personal communication).

Environmental variables

Soils We obtained soil Cation Exchange Capacity at pH 7 (CEC) and $5 \mathrm{~cm}$ depth from SoilGrids (soilgrids. org - downloaded in December 2016), which provides the data at $250 \mathrm{~m}$ resolution (Hengl et al. 2017). Because CEC is the only easily available high-resolution GIS layer that is related to soil nutrients, it has been applied in ecological studies in the tropics (Figueiredo et al. 2018; Levis et al. 2017; McMichael et al. 2014; Poorter et al. 2015). However, the usefulness of CEC to model plant communities in Amazonia is questionable (Moulatlet et al. 2017; Zuquim et al. 2017), because CEC is not a measure of current nutrient availability, but rather a measure of how well the soil is able to retain cations. The use of CEC is particularly problematic in Amazonia, where more than $90 \%$ of CEC is often occupied by aluminum (Quesada et al. 2011), which is not a plant nutrient. Therefore, we used a recently produced digital map of soil Exchangeable Base Cation Concentration (K, Mg, Ca) (Zuquim 2017) as an indicator of soil nutrient conditions for plants in natural vegetation (Moulatlet et al. 2017). This layer was developed by compiling field measurements of exchangeable base concentration from several databases and combining them with indirect cation concentration estimates based on the occurrence of indicator plant species (Zuquim et al. 2014). The compiled data were interpolated using ordinary kriging in pixels of 6 $\operatorname{arcmin}(\sim 11 \times 11 \mathrm{~km})$ and validated with 194 soil samples of the RAINFOR project (Zuquim 2017; Zuquim et al., in review).

Climate We obtained current estimates of Annual Mean Temperature, Temperature Annual Range, Mean Temperature of Coldest Quarter, Annual Precipitation, Precipitation Seasonality and Precipitation of Driest Quarter (bio1, 7 12, 15 and 17) from Climatologies at high resolution (30 arcsec pixels) for the earth's land surface areas (CHELSA). CHELSA makes available future climate layers for 2050 based on five prediction models of the Coupled Model Intercomparison Project Phase 5 (CMIP5) from the last Intergovernmental Panel on Climate Change report. CMIP5 are multimodel ensemble simulations that provide robust estimates of future climatic conditions (Sillmann et al. 2013). The different climate scenarios are interdependent and contain similar biases, simplifications, parameterizations of processes, but they produce different climatic outputs. We therefore included high resolution models from CHELSA based on results from 5 different climatology research groups: Euro-Mediterranean Center on Climate Change (CMCC), Community Earth System Model (CESM), 
Model for Interdisciplinary Research on Climate (MIROC), Max-Planck Institute Earth System Model (MPI-ESM) and Institut Pierre Simon Laplace (IPSL). These models were selected in order to cover a wide range of variation and they are well spread in the climate model genealogy (Knutti et al. 2013). Models from MPI (MPI-ESM-MR) and IPSL (IPSL-CM5A-LR) produced artifactual North-South straight lines and their results are not reported. Nevertheless, the remaining three models applied here were in extreme nodes of the climate model genealogy and, therefore, are expected to collectively represent the range of possible future climatic conditions well.

We also accounted for two different Representative Concentration Pathways (RCP) for Greenhouse gas concentration trajectories. RCP 8.5 is a baseline scenario that assumes no climate policy and, thus, emissions would continue to rise throughout the twenty-first century. It models future climatic conditions based on the projection of the current trends in economy, demography and energy use, without any specific climate mitigation target (Riahi et al. 2011). RCP 8.5 future models are hereafter referred to as business-as-usual (BAU) scenarios.

RCP 4.5 is an optimistic but still achievable scenario as it assumes that $\mathrm{CO}_{2}$ concentration will peak around 2040 and then decline as a consequence of governmental incentive policies to lower carbon emission and concentration, e.g. cleaner energy technologies, carbon capture and geologic storage, and forest land expansion (Thomson et al. 2011). RCP 4.5 is hereafter referred to as the governance (GOV) scenarios.

We did not include RCP 2.6 scenarios, because they assume that $\mathrm{CO}_{2}$ concentration peaks between 2010 and 2020 with emissions declining substantially thereafter (van Vuuren et al. 2011a). These scenarios depend on massive improvements in energy efficiency, reduced use of fossil fuels and massive implementation of negative emission technologies (van Vuuren et al. 2011b), which have been largely absent from climate policy actions so far (Anderson and Peters 2016). Moreover, the trend in $\mathrm{CO}_{2}$ concentration from 1958 to 2018 has been a steady linear increase (Keeling and Keeling 2017) and there is no reason to believe this trend to change in the short window from now to 2020 .

In summary, we used six climatic scenarios for 2050, divided into two major groups. One group contains three scenarios that assume a reduction in $\mathrm{CO}_{2}$ emissions due to governance climatic policies (GOV) and the other group contains three scenarios that assume business- as-usual emission rates (BAU). Each of the three scenarios in each group was produced by a different research team (CMCC-CMS, MIROC5 and CESM1BGC) that considered different algorithms and climatological assumptions.

Data analysis

All environmental layers were re-scaled to an aprox. $5 \mathrm{~km} \times 5 \mathrm{~km}$ grid for analysis. We then run MaxEnt models to construct presence-background current species distribution models for 35 species of trees, lianas, monocot herbs, and palms. To achieve a balance between goodness-of-fit and predictive ability, we tuned MaxEnt model settings for each species (Merow et al. 2013; Syfert et al. 2013; Warren et al. 2014; Halvorsen et al. 2016) by running 32 models per species representing combinations of the features Linear, Linear-Quadratic, Linear-Quadratic-Product and LinearQuadratic-Hinge with eight regularization multipliers (values from 0.5 to 4 at 0.5 intervals). We selected the combination of settings that produced models with the lowest value of Akaike information criterion with a correction for small sample sizes (AICc) for each species. We established a minimum value of full Area Under the Curve (AUC based on the full dataset) of 0.69 to consider the model adequate to be included in further analysis. To obtain maps of habitat suitability under future climatic conditions, we used the modelled species-environment relationships for current conditions and replaced the current climatic data with the projected climatic conditions in 2050 for spatial prediction.

All models were run separately using two different sets of environmental layers, one including five bioclimate layers only (hereafter, climate-only models) and the other including five climate layers and two soil layers (hereafter, climate+soil models). Climate-only and climate+soil species distribution models were generated for each of the seven climatic scenarios (one for the current climate and six future scenarios). To calculate the predicted suitable area for present and future species distribution models, we generated binary ecological niche models by applying a threshold value on the occurrence probability for each of the MaxEnt models. Threshold value for each model was defined as the maximum training sensitivity plus specificity (Liu et al. 2013). We calculated the ratio of the predicted surface areas to quantify the differences in 
the areas predicted by a) climate and climate+soil models; b) present and future models and c) governance and business-as-usual future models. The ratio between the compared predicted areas was logarithmically transformed (base 2), which converts the ratio to an index that is symmetric around zero and in which a 2-fold difference in the areas being compared always corresponds to one unit difference in index value. We also applied a one-way ANOVA with a posteriori Tukey-test to evaluate the differences between AUC of climateonly and climate+soil models and between the areas predicted by different climate model algorithms.

All the analyses were done in R environment, using the packages "raster" (Hijmans 2016) for raster manipulation and calculations, "dismo" (Hijmans et al. 2017) for building MaxEnt models, and "ENMeval" (Muscarella et al. 2014, 2017) for model evaluation. Data from GBIF and iDigBio were downloaded using the package "spocc" (Chamberlain 2016) and geographical outliers were removed with the package "biogeo" (Robertson 2016).

\section{Results}

Comparisons between climate-only and climate+soil models

Out of the 35 species assessed, 25 had its current distribution models considered satisfactory (AUC $\geq 0.69$; Table 1). Information on the models for the 10 species with AUC $<0.69$ is presented in supplementary materials (Table S1) but the results of these models were not considered in the subsequent analyses.

In general, the AUC values of current species distribution models were rather similar whether, besides climate, soil variables were included or not (Table 1) and no significant difference was found between climate-only and climate+soil AUCs of the models (ANOVA diff $=0.02$, adj. $p=0.48$ ). For 14 out of 25 climate+soil current species distribution models, the variable with the highest relative importance was bioclimatic, and in 11 models, it was edaphic.

The sizes of climate-only and climate+soil modelled suitable areas (calculated based on the binary models) were correlated (Pearson's $r=0.71$ ). The correlation between the sizes of suitable areas predicted by climate-only and climate+soil in future models varied between 0.68 and 0.72 depending on the future scenario considered.

The inclusion of soil variables affected the size of predicted suitable areas based on binary maps. For nearly half of the species, climate-only models predicted larger future suitable areas than climate+soil models (Fig. 1).

A visual inspection of the maps suggests that the inclusion of soils affected not only the total suitable area, but also its spatial distribution, especially in the future predictions. For example, climate-only models predicted that the upper Rio Negro area in northwestern Brazil would become climatically suitable in 2050 for the palm Iriartea deltoidea (Fig. 2) and for the understory herb Heliconia schumanniana (Fig. 3). However, when soil variables were included in the model, low probability values were assigned to these same areas, possibly because of the extremely nutrient-poor soils that are found there. On the other hand, the Andean forelands were only predicted as suitable for Iriartea deltoidea when soils were taken into account. For the herb Goeppertia fragilis (Fig. 4) and the tree Nectandra turbacensis (Fig. 5), climate-only models clearly predicted larger suitable areas in the future than climate+soil models did, with the latter nested within the former. Finally, soil data contributed very little to the models of the liana Macherium amplum, and for this species the climate-only and climate+soil models were roughly similar (Fig. 6). The current and future suitability maps of the species that were not mentioned above are presented in the Supplementary material (Figs. S1-S20).

Comparison between present and future scenarios

Species that had their current suitable area reduced in the future according to climate+soil models, were predicted to have more extreme suitable-area losses under business-asusual scenarios than under governance scenarios (Fig. 7, Table S2). Heliconia schumanniana (Fig. 3) is an example of a species whose suitable area is predicted to contract in the future, especially when soils are taken into account. Species suitable areas were reduced on average to between $1 / 7$ th and $1 / 10$ th of their current extent (corresponding to area index values between -2.8 and -3.3 ) under the business-as-usual scenarios (Fig. 7b,d), and to between $1 /$ 4th and 1/9th (corresponding to area index values between -2 and -3.2) under the governance scenarios (Fig. 7a,c). 
Table 1 Details of the best distribution models based on current climatic conditions for each of the 25 Amazonian plant species as obtained with the maximum entropy algorithm (Maxent). Two models are shown for each species, one including bioclimatic variables (bio) only (Clim-only models), the other also including the concentration of exchangeable bases ("Nutrients"; the sum of $\mathrm{Ca}, \mathrm{Mg}$ and $\mathrm{K}$ concentrations in the soil) and cation exchange capacity (CEC) of the soil (Clim+soil models). Species are sorted in order of decreasing contribution of Nutrients and then CEC to clim+soil models. Only species with AUC values $>0.69$ in at least one of the models are shown here; results for the other species are in Supplementary Table 1. The bioclimatic variables are annual mean temperature ("bio1"), temperature annual range ("bio7"), annual precipitation ("bio12"), precipitation seasonality ("bio15") and precipitation of driest quarter ("bio17"). For more details, see http://chelsa-climate.org/bioclim/. "Feature" refers to the mathematical transformations of covariates applied by models to allow complex relationships: linear (L), linear quadratic (LQ), linear-quadratic-product (LQP) and linear-quadratic-hinge (LQH). The regularization multiplier ("RM") is the penalty weight on model complexity. Full AUC is the Area Under the Curve for models using the full occurrences dataset (as opposed to the mean AUC that is based on training datasets). The best model was defined as the one with the lowest value of Akaike information criterion with a correction for small sample sizes (AICc)

\begin{tabular}{|c|c|c|c|c|c|c|c|c|c|c|c|}
\hline Species & bio1 & bio7 & bio12 & bio 15 & bio 17 & Nutrients & CEC & Feature & $\mathrm{RM}$ & Full AUC & Model \\
\hline \multirow[t]{2}{*}{ Monotagma ulei } & 0.1 & 19.9 & 8 & 0.5 & 6.6 & 64.1 & 0.8 & LQP & 0.5 & 0.83 & Clim+soil \\
\hline & 6.4 & 61.6 & 0 & 9.3 & 22.8 & NA & NA & LQP & 0.5 & 0.84 & Clim-only \\
\hline \multirow[t]{2}{*}{ Henriquezia nitida } & 0 & 14.5 & 1 & 3 & 2.2 & 59.5 & 19.7 & LQH & 3 & 0.96 & Clim+soil \\
\hline & 4.1 & 61.7 & 4.1 & 2.8 & 27.3 & NA & NA & LQH & 2.5 & 0.95 & Clim-only \\
\hline \multirow[t]{2}{*}{ Goeppertia zingiberina } & 6 & 16.6 & 13.1 & 6.7 & 0.6 & 52.4 & 4.5 & LQP & 0.5 & 0.75 & Clim+soil \\
\hline & 25.7 & 42.4 & 6.6 & 3 & 22.4 & NA & NA & LQP & 0.5 & 0.75 & Clim-only \\
\hline \multirow[t]{2}{*}{ Goeppertia fragilis } & 7.4 & 20.7 & 1.3 & 1.4 & 13.9 & 48.1 & 7.2 & LQP & 0.5 & 0.87 & Clim+soil \\
\hline & 0.1 & 20.7 & 0 & 31.3 & 47.9 & NA & NA & LQP & 0.5 & 0.85 & Clim-only \\
\hline \multirow[t]{2}{*}{ Leopoldinia pulchra } & 5.5 & 2.3 & 1.9 & 4.9 & 7.6 & 43.5 & 34.3 & LQP & 1.5 & 0.89 & Clim+soil \\
\hline & 0.5 & 74.8 & 7 & 12.1 & 5.5 & NA & NA & LQP & 2 & 0.88 & Clim-only \\
\hline \multirow[t]{2}{*}{ Machaerium ferox } & 7.2 & 1.6 & 32.9 & 5.7 & 5.7 & 31.4 & 15.4 & LQ & 0.5 & 0.81 & Clim+soil \\
\hline & 40.5 & 42 & 13.9 & 2.6 & 1 & NA & NA & LQ & 0.5 & 0.8 & Clim-only \\
\hline \multirow[t]{2}{*}{ Poecilanthe effusa } & 1.8 & 10.9 & 39.3 & 5.9 & 3.8 & 30.4 & 7.9 & LQP & 1 & 0.71 & Clim+soil \\
\hline & 44 & 42 & 4.2 & 1.6 & 8.1 & NA & NA & LQ & 0.5 & 0.69 & Clim-only \\
\hline \multirow[t]{2}{*}{ Manilkara huberi } & 17.9 & 10.9 & 24.8 & 4.4 & 4 & 27.8 & 10.2 & LQP & 1 & 0.76 & Clim+soil \\
\hline & 37.6 & 33.3 & 13.7 & 5.5 & 9.9 & NA & NA & LQP & 0.5 & 0.75 & Clim-only \\
\hline \multirow[t]{2}{*}{ Caryocar glabrum } & 1.2 & 6.5 & 12.1 & 1.9 & 34.7 & 25.8 & 17.8 & LQP & 0.5 & 0.69 & Clim+soil \\
\hline & 13.9 & 51.3 & 2.6 & 24.7 & 7.4 & NA & NA & LQ & 0.5 & 0.68 & Clim-only \\
\hline \multirow[t]{2}{*}{ Nectandra turbacensis } & 6.8 & 0 & 8.3 & 0 & 0 & 22.5 & 62.4 & $\mathrm{~L}$ & 2 & 0.83 & Clim+soil \\
\hline & 0.9 & 99.1 & 0 & 0 & 0 & NA & NA & $\mathrm{L}$ & 2 & 0.72 & Clim-only \\
\hline \multirow[t]{2}{*}{ Caryocar microcarpum } & 2.8 & 3.6 & 11.3 & 1.1 & 1.4 & 20.7 & 59 & LQ & 0.5 & 0.78 & Clim+soil \\
\hline & 16.3 & 68.4 & 1.1 & 4.1 & 10.1 & NA & NA & LQP & 0.5 & 0.77 & Clim-only \\
\hline \multirow[t]{2}{*}{ Machaerium multifoliolatum } & 4.7 & 10.7 & 6.2 & 0 & 49.4 & 20.4 & 8.6 & $\mathrm{~L}$ & 1 & 0.71 & Clim+soil \\
\hline & 0 & 8.2 & 0 & 91.8 & 0 & NA & NA & $\mathrm{L}$ & 3 & 0.66 & Clim-only \\
\hline \multirow[t]{2}{*}{ Machaerium amplum } & 0 & 58.1 & 2.5 & 0 & 27.2 & 12.2 & 0 & LQP & 4 & 0.77 & Clim+soil \\
\hline & 5.9 & 6.9 & 0.9 & 7.8 & 78.5 & NA & NA & LQP & 1.5 & 0.78 & Clim-only \\
\hline \multirow[t]{2}{*}{ Hylaeanthe hexantha } & 1.8 & 9.5 & 21.5 & 20.9 & 6.7 & 11.7 & 27.9 & LQP & 1 & 0.79 & Clim+soil \\
\hline & 11.6 & 28.5 & 24.6 & 18.9 & 16.3 & NA & NA & LQP & 0.5 & 0.74 & Clim-only \\
\hline \multirow[t]{2}{*}{ Couepia dolichopoda } & 2.5 & 61.7 & 0 & 0 & 5.4 & 9.6 & 20.7 & $\mathrm{~L}$ & 1 & 0.93 & Clim+soil \\
\hline & 2.4 & 19.5 & 0 & 0 & 78.1 & NA & NA & LQH & 2 & 0.94 & Clim-only \\
\hline \multirow[t]{2}{*}{ Socratea exorrhiza } & 7.1 & 31.5 & 6.4 & 1.4 & 34.4 & 6.5 & 12.6 & LQ & 0.5 & 0.73 & Clim+soil \\
\hline & 6.9 & 12.1 & 4.3 & 30.6 & 46.1 & NA & NA & LQP & 0.5 & 0.72 & Clim-only \\
\hline \multirow[t]{2}{*}{ Heliconia schumanniana } & 2.3 & 33.5 & 12.8 & 0.8 & 16.6 & 6.4 & 27.6 & LQP & 1.5 & 0.97 & Clim+soil \\
\hline & 27.7 & 16.4 & 3.1 & 29.9 & 22.9 & NA & NA & LQP & 1 & 0.95 & Clim-only \\
\hline Pleonotoma jasminifolia & 3.9 & 0 & 11.7 & 1 & 2.1 & 3.8 & 77.4 & LQP & 1.5 & 0.83 & Clim+soil \\
\hline
\end{tabular}


Table 1 (continued)

\begin{tabular}{llllllllllll}
\hline Species & biol & bio7 & bio12 & bio15 & bio17 & Nutrients & CEC & Feature & RM & Full AUC & Model \\
\hline \multirow{2}{*}{ Oenocarpus bataua } & 11.6 & 67.4 & 14.3 & 2.4 & 4.3 & NA & NA & LQP & 0.5 & 0.78 & Clim-only \\
& 11 & 13.5 & 24.1 & 1 & 29.2 & 2.1 & 19.2 & LQP & 2 & 0.81 & Clim+soil \\
Iriartea deltoidea & 5 & 9.4 & 0.1 & 83.8 & 1.7 & NA & NA & LQ & 1 & 0.77 & Clim-only \\
& 21.4 & 20.7 & 12.7 & 0 & 16.1 & 0.9 & 28.2 & LQH & 3.5 & 0.83 & Clim+soil \\
Martinella obovata & 10 & 31.6 & 2.4 & 31.8 & 24.2 & NA & NA & LQP & 1.5 & 0.82 & Clim-only \\
& 38.1 & 2.3 & 14.2 & 0 & 45.2 & 0.2 & 0 & L & 3.5 & 0.71 & Clim+soil \\
Renealmia breviscapa & 2.8 & 3.5 & 0.1 & 88.8 & 4.8 & NA & NA & LQP & 1 & 0.68 & Clim-only \\
Ischnosiphon martianus & 2.7 & 0.3 & 27 & 5.4 & 34.5 & 0 & 30 & LQP & 3.5 & 0.86 & Clim+soil \\
& 5.1 & 36.5 & 0.1 & 55.4 & 2.9 & NA & NA & LQ & 0.5 & 0.83 & Clim-only \\
Rourea cuspidata & 0 & 11.6 & 43 & 2.5 & 8.7 & 0 & 34.1 & LQ & 3 & 0.91 & Clim+soil \\
& 25 & 37.9 & 5 & 11.5 & 20.5 & NA & NA & LQP & 0.5 & 0.91 & Clim-only \\
Goeppertia loeseneri & 0 & 46.5 & 10.4 & 0 & 33.8 & 0 & 9.3 & LQ & 3.5 & 0.74 & Clim+soil \\
& 41.4 & 7.8 & 0.4 & 20.8 & 29.6 & NA & NA & LQP & 1 & 0.75 & Clim-only \\
& 0.2 & 0 & 4.4 & 0 & 89.9 & 0 & 5.5 & L & 3 & 0.9 & Clim+soil \\
& 9.9 & 4.8 & 0 & 56.6 & 28.7 & NA & NA & LQH & 1.5 & 0.91 & Clim-only \\
\hline & & & & & & & & & &
\end{tabular}

In an extreme case, a species was predicted to have its area reduced to $1 / 315$ th (area index value -8.3 ) under a business-as-usual scenario and to $1 / 34$ th (area index value -5.1 ) under a governance scenario, in relation to current suitable area (Fig. 7). Suitable areas for Couepia dolichopoda (Fig. S3) and Henriquezia nitida (Fig. S6) were predicted to be reduced to practically zero under certain climate-only future scenarios. No suitable area was predicted for Leopoldina pulchra in the climateonly business-as-usual scenario of CMCC-CMS model (Fig. S9). On the other hand, for between 9 and 13 species, future conditions appear to provide more suitable area than current ones (Fig. 7), even when soils and climate are taken into account together (e.g. Nectandra turbacensis, Fig. 6).

\section{Comparison among future scenarios}

The predictions using three climatologies from different research groups were relatively consistent for the models with the same projected $\mathrm{CO}_{2}$ concentration, even though models including CMCC-CM5 climate projections tended to predict slightly smaller suitable areas than when including CESM1-BGC or MIROC5 projections in the models (Fig. S21). However, for most of the plant species modelled, the predicted future suitability using business-as-usual climate scenarios tended to predict less area than models using governance scenarios, regardless of the research group (Fig. 8).

\section{Discussion}

In this study we have found that 1) the projection of future habitat suitability of species based on climateonly models can considerably overestimate suitable areas for species with strong soil affinity; 2) at the same time, the inclusion of soil variables in our models increased the predicted suitable area in the future for other species, which can be considered good news for these species; 3) for half of the species, future suitable areas were predicted to be smaller than current ones if no climate policies are adopted; two of the species were predicted to have no future suitable area at all; 4) for some species inhabiting the fringes of Amazonia, larger suitable areas were predicted for the future; and 5) governance scenarios tended to predict larger suitable areas in the future than business-as-usual scenarios.

For species limited by soil conditions, we hypothesized that climate-only models would predict larger suitable areas in the future than when soils where also taken into account. Climatically suitable areas 


\section{Climate+soil/climate-only}
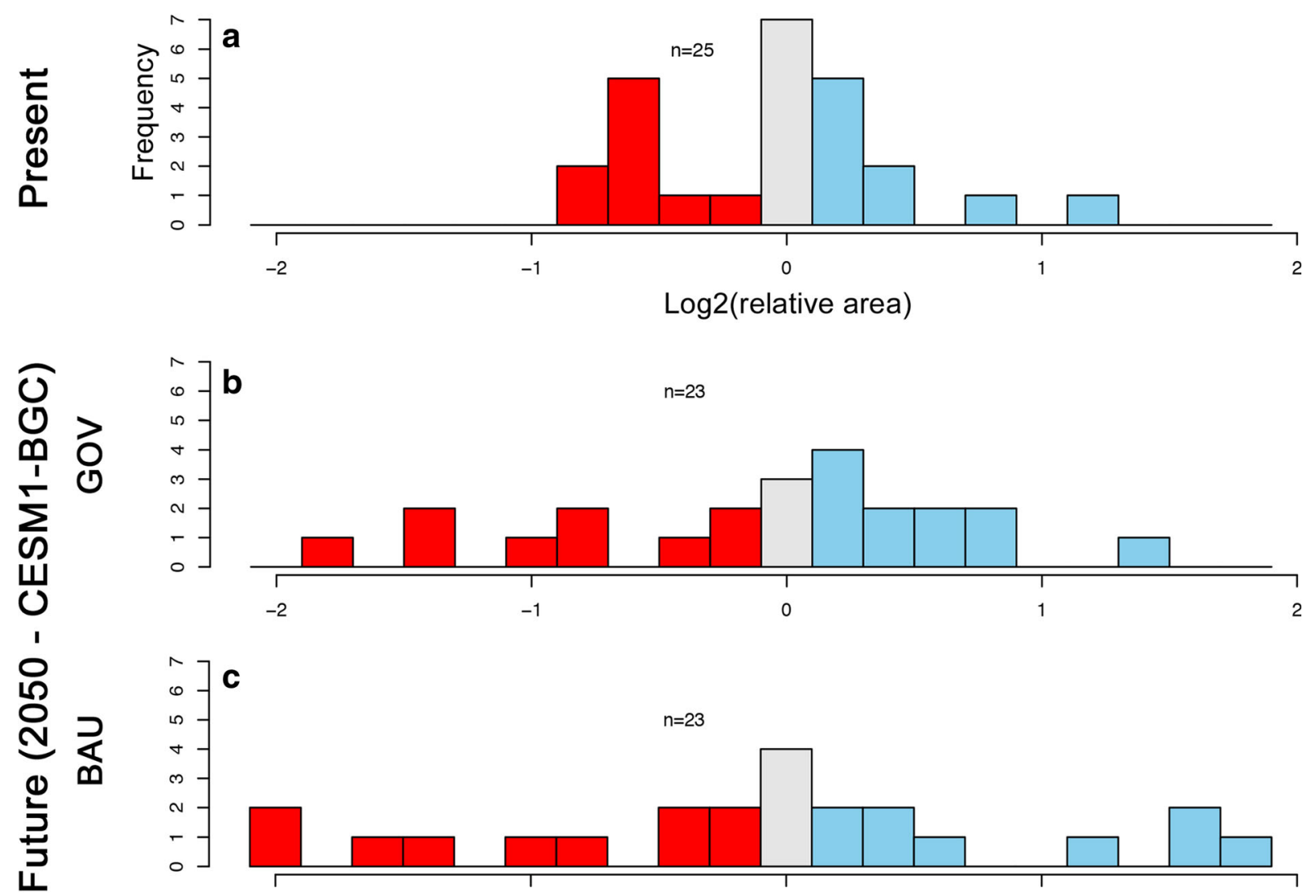

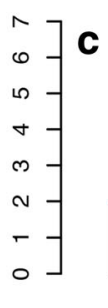

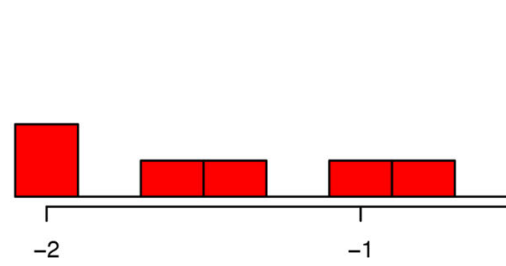

Fig. 1 Frequency histograms of the logarithmically transformed (base 2) ratio between the suitable areas as predicted using climateonly and climate+soil models for each of $n$ plant species in Amazonia. Climatic variables were based either on present climate (a) or on climatic predictions for 2050 using CESM1-BGC Governance [GOV, (b)] and Business-as-usual [BAU, (c)] scenarios. Negative values (red) mean that the climate-only model predicted larger suitable areas than the climate+soil model for the same

$n=23$

for a species may have soils that are not adequate for its establishment. In addition, not only difference in the size of the areas where expected, but also, in the spatial configuration. In fact, that was observed for several species, e.g. Renealmia breviscapa, Heliconia schumanniana and Iriartea deltoidea. For these three species, the upper Rio Negro region was predicted to be suitable by climate-only-models. However, the dominant soils in that area are more nutrient-poor than in the areas where these species are currently known to occur, which possibly makes the area unsuitable for them. Indeed, climate+soil models did not predict the upper Rio Negro as a suitable area for these species in the future. According to these models, future suitable areas are concentrated along the Andean foreland, where soils tend to be richer in nutrients (Quesada et al. 2010).

Our results reinforce earlier findings that soils are important for the understanding of current species distributions in Amazonia (Tuomisto et al. 2016; Costa et al. 2009) and that the inclusion of soil variables can improve broad-scale species distribution models when compared to the performance of 


\section{Iriartea deltoidea}

\section{Climate-only}
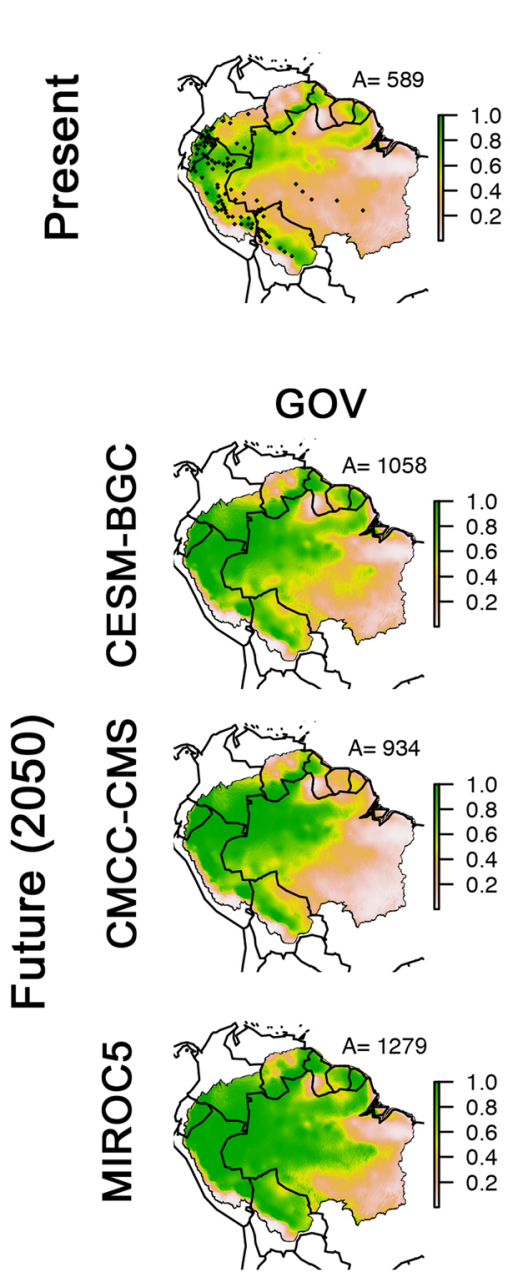

Climate+soil

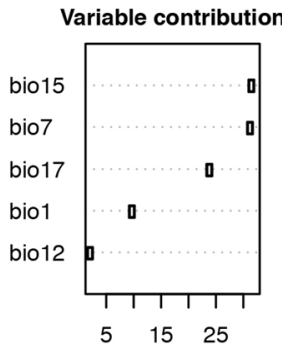

BAU
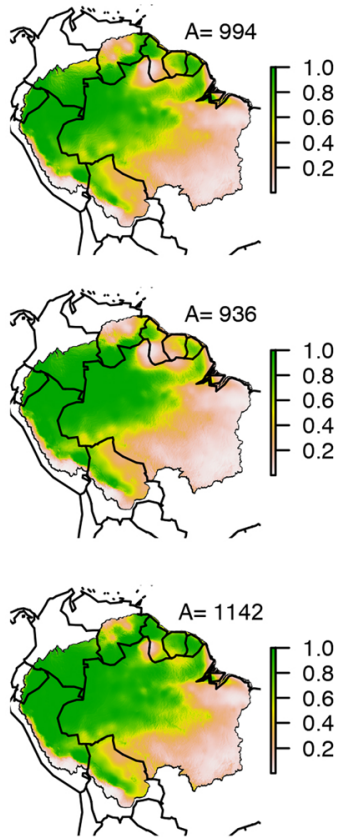

Fig. 2 Predictions of environmentally suitable areas for the occurrence of the palm Iriartea deltoidea using climate-only models (two first columns) and climate+soil models (two last columns). The first row presents the modelled habitat suitability under current environmental conditions (with black dots indicating species occurrence records), and the scatterplots of the relative contribution of each variable to the model (in \%). For variable names in climate-only models (Figueiredo et al. 2018; Velazco et al. 2017). Species distribution models including remote sensing layers to represent vegetation properties (e.g. leaf area index, greenness, tree cover) have also been more successful than climate-only models (Buermann et al. 2008). This may ultimately also reflect the influence of soils, which can affect various forest properties (Quesada et al. 2012; Higgins et al.
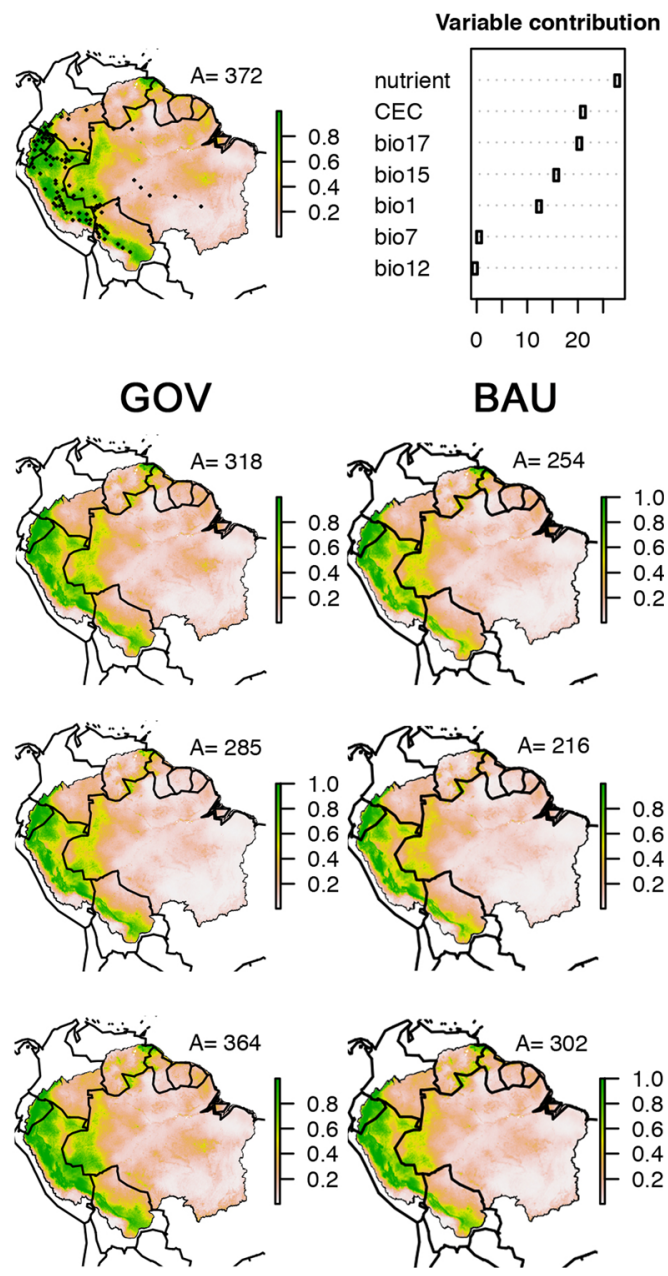

full, see Table 1. Future models were based on climatologies developed by three different research groups (CESM1-BGC, CMCC-CMS and MIROC5) taking into account atmospheric $\mathrm{CO}_{2}$ concentration scenarios under governance (GOV) and business-as-usual (BAU) climatic policies. The estimated suitable area $\left(\mathrm{A}\right.$, in $\left.1000 \mathrm{~km}^{2}\right)$ was estimated for each model after applying a threshold on the relative probability values

2015) especially in areas where climate is relatively homogeneous. Consequently, appropriate representation of soil conditions should be included in any attempt to forecast future distributions of species. This is challenging because, even though considerable effort has been invested in producing digital soil maps that cover the entire world (Nachtergaele et al. 2012; Dijkshoorn et al. 2005; Hengl et al. 2017), in 


\section{Heliconia schumanniana}

\section{Climate-only}
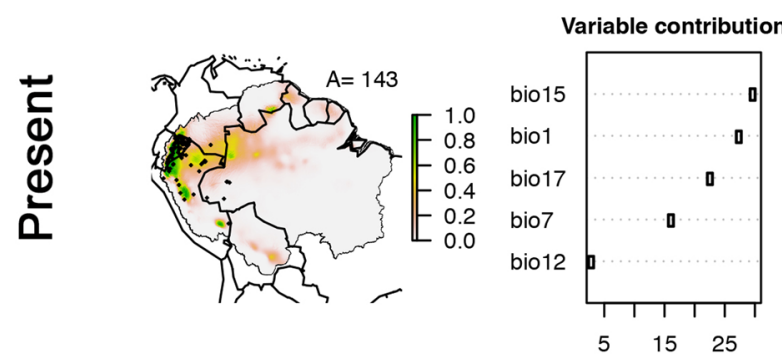

GOV
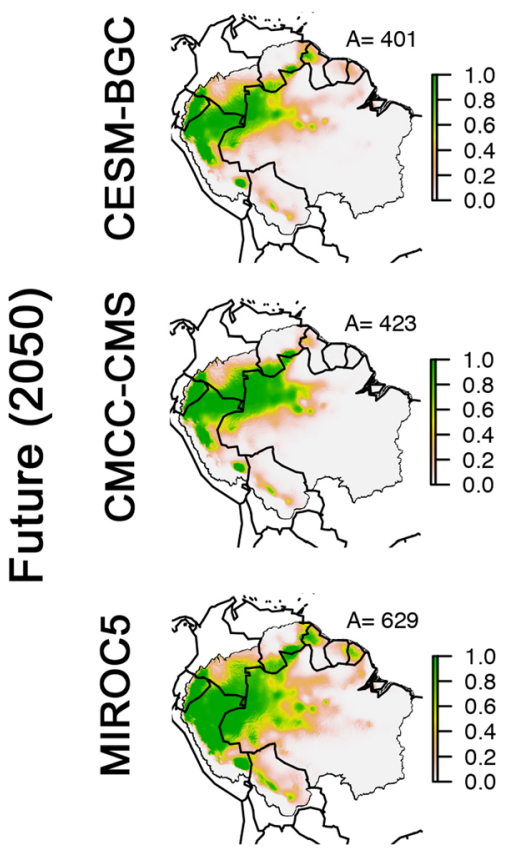

BAU
Climate+soil
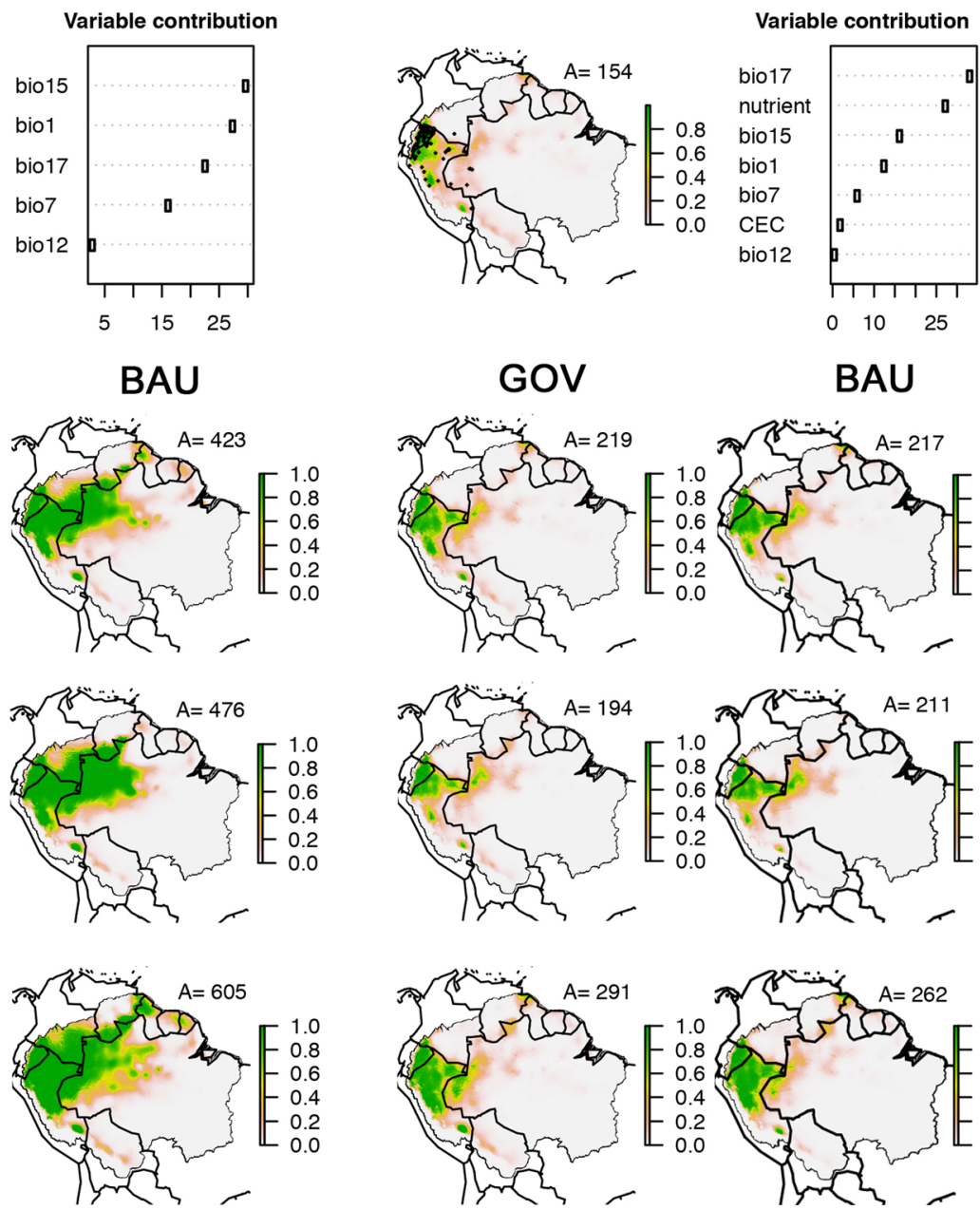

variable names in full, see Table 1. Future models were based on climatologies developed by three different research groups (CESM1-BGC, CMCC-CMS and MIROC5) taking into account atmospheric $\mathrm{CO}_{2}$ concentration scenarios under governance (GOV) and business-as-usual (BAU) climatic policies. The estimated suitable area (A, in $\left.1000 \mathrm{~km}^{2}\right)$ was estimated for each model after applying a threshold on the relative probability values data-poor areas, such as Amazonia, these maps still suffer from serious inaccuracies (Moulatlet et al. 2017). We mitigated this problem by adding a exchangeable cation concentration map produced specifically for the Amazonian region (Zuquim 2017) and with a greater density of input data points when compared with global soil maps. This contributed to a better representation of environmental variation and thus better current species distribution and future suitability models.

For few species, the total suitable areas predicted by climate+soil models were relatively similar for current and future scenarios. In some cases, the areas predicted by climate+soil models were even larger than climate-only predicted suitable areas for the future. This is probably because we assumed that 


\section{Goeppertia fragilis}

\section{Climate-only}
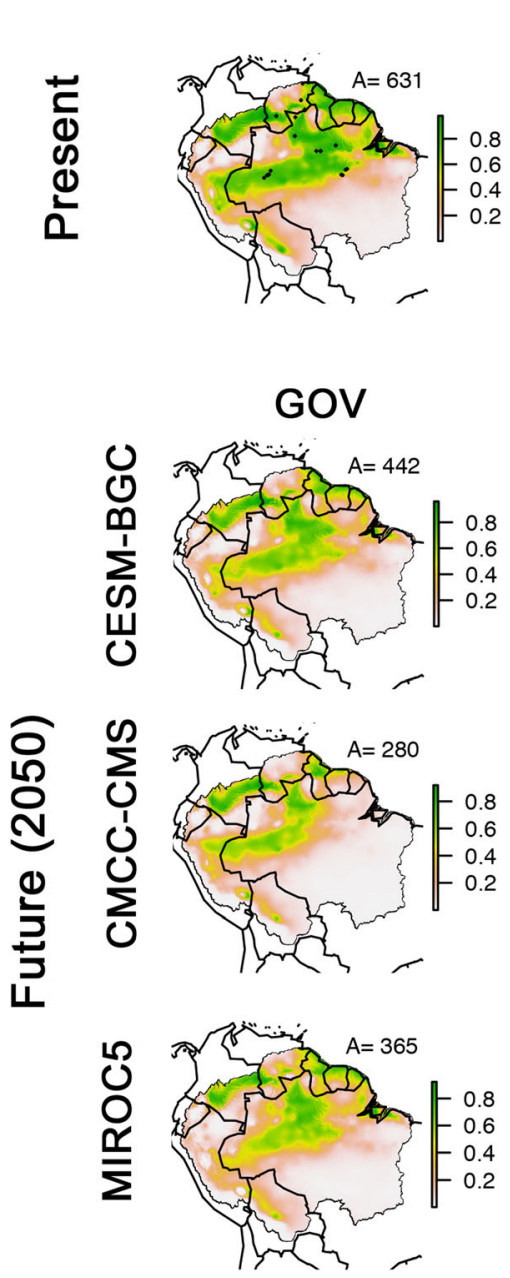

\section{Climate+soil}
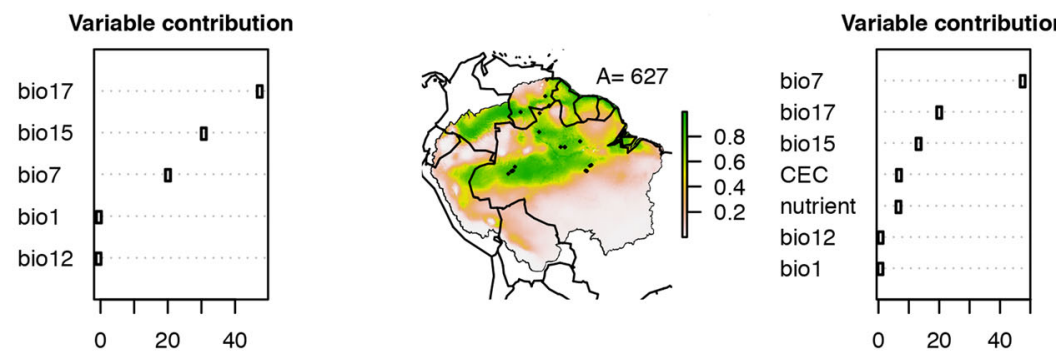

BAU
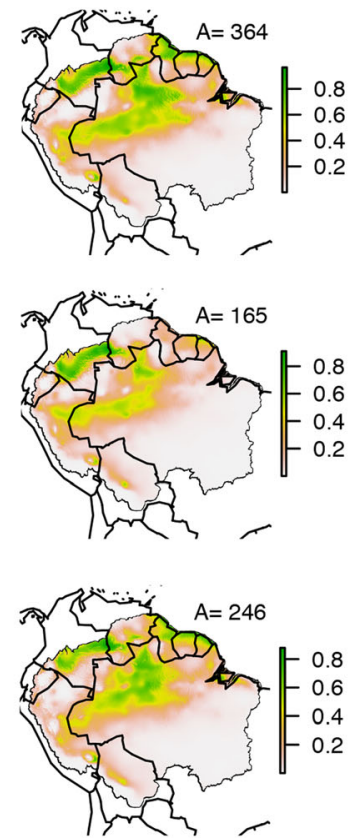

Fig. 4 Predictions of environmentally suitable areas for the occurrence of the understory herb Goeppertia fragilis using climateonly models (two first columns) and climate+soil models (two last columns). The first row presents the modelled habitat suitability under current environmental conditions (with black dots indicating species occurrence records), and the scatterplots of the relative contribution of each variable to the models (in \%). For variable

in the time scale modelled, soils will not change as fast as climate and thus, current and future soil conditions are similar. In this scenario, species that are more determined by soil than climate would be less prone to be affected by climate change. In any case, these models illustrate that climate-only models are incomplete when assessing future ranges of plant species.

names in full, see Table 1. Future models were based on climatologies developed by three different research groups (CESM1-BGC, CMCC-CMS and MIROC5) taking into account atmospheric $\mathrm{CO}_{2}$ concentration scenarios under governance (GOV) and businessas-usual (BAU) climatic policies. The estimated suitable area (A, in $1000 \mathrm{~km}^{2}$ ) was estimated for each model after applying a threshold on the relative probability values

In the long term, drought will likely cause biodiversity and biomass loss, since moisture availability partially constrains plant species richness (Kessler et al. 2011; Tuomisto et al. 2014; Esquivel-Muelbert et al. 2017a) and above-ground biomass (Saatchi et al. 2007). For nearly half of the species modelled here, the projected future suitable areas were smaller than current. Similarly, Miles et al. (2004) estimated 


\section{Nectandra turbacensis}

\section{Climate-only}
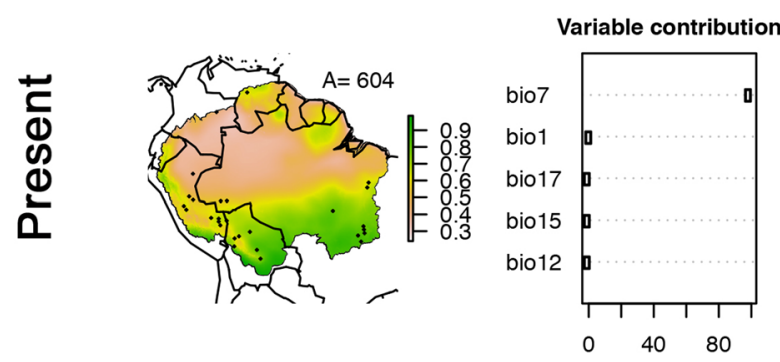

GOV
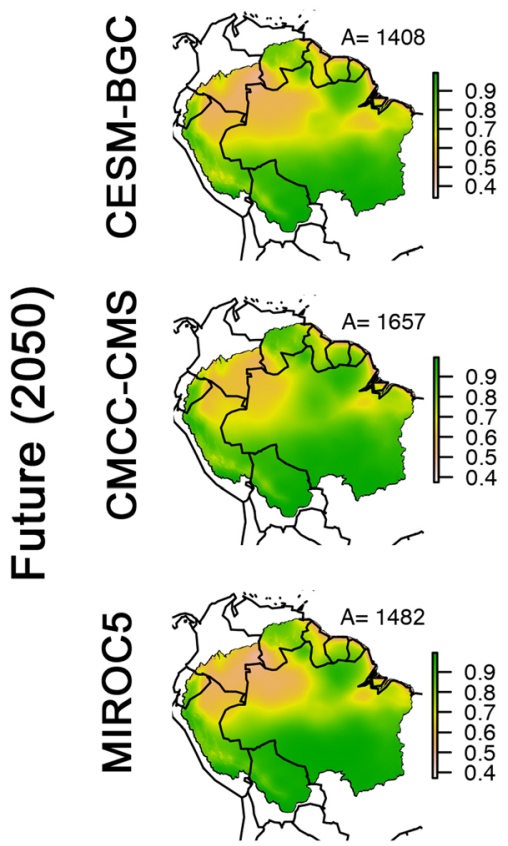

BAU
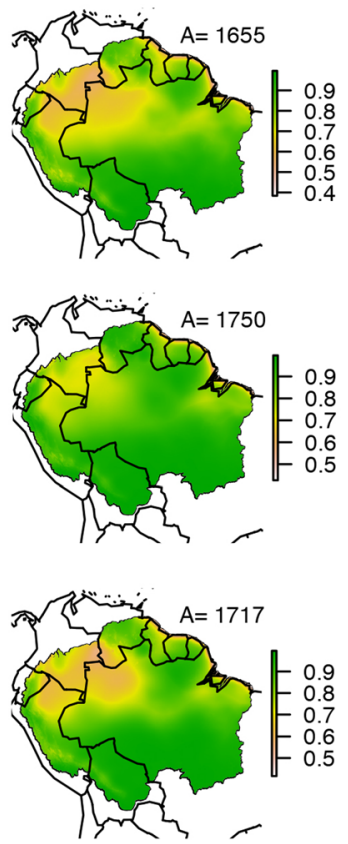

Climate+soil
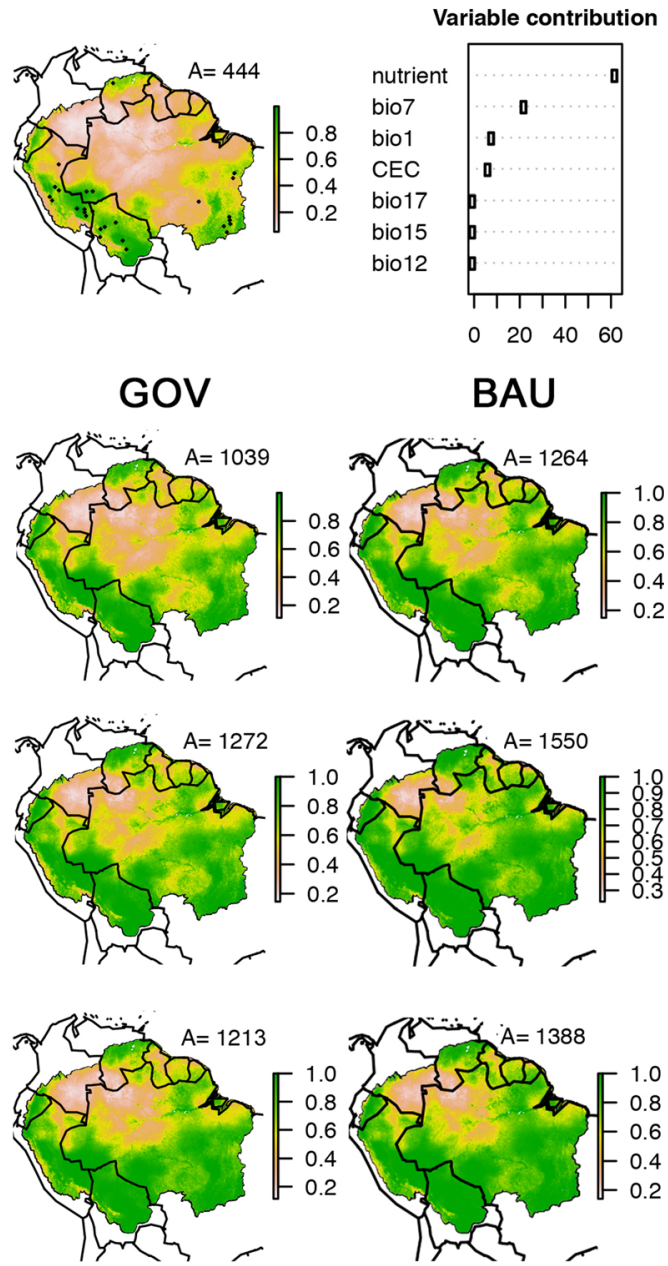

Fig. 5 Predictions of environmentally suitable areas for the occurrence of the tree Nectandra turbacensis using climate-only models (two first columns) and climate+soil models (two last columns). The first row presents the modelled habitat suitability under current environmental conditions (with black dots indicating species occurrence records), and the scatterplots of the relative contribution of each variable to the models (in \%). For variable

that 30 out of 69 Amazonian tree species populations would decrease in the future due to climate change. On the other hand, Feeley et al. (2012) have projected less dramatic loss of favorable areas for species in the future (8-12\%), assuming that species have enough plasticity to adapt to rising temperatures in addition to migrating. Nevertheles, none of the previous studies properly assessed the constraints imposed by soil names in full, see Table 1. Future models were based on climatologies developed by three different research groups (CESM1-BGC, CMCC-CMS and MIROC5) taking into account atmospheric $\mathrm{CO}_{2}$ concentration scenarios under governance (GOV) and businessas-usual (BAU) climatic policies. The estimated suitable area (A, in $1000 \mathrm{~km}^{2}$ ) was estimated for each model after applying a threshold on the relative probability values

specialization. Our models suggest that many species have smaller suitable areas in the future when soil limitations are taken into account. Therefore, the projected reduction in suitable areas, population sizes and species viability under climate change can be expected to be worse than projected before.

In our dataset, part of the species for which projected future suitable areas were larger than 


\section{Machaerium amplum}

\section{Climate-only}
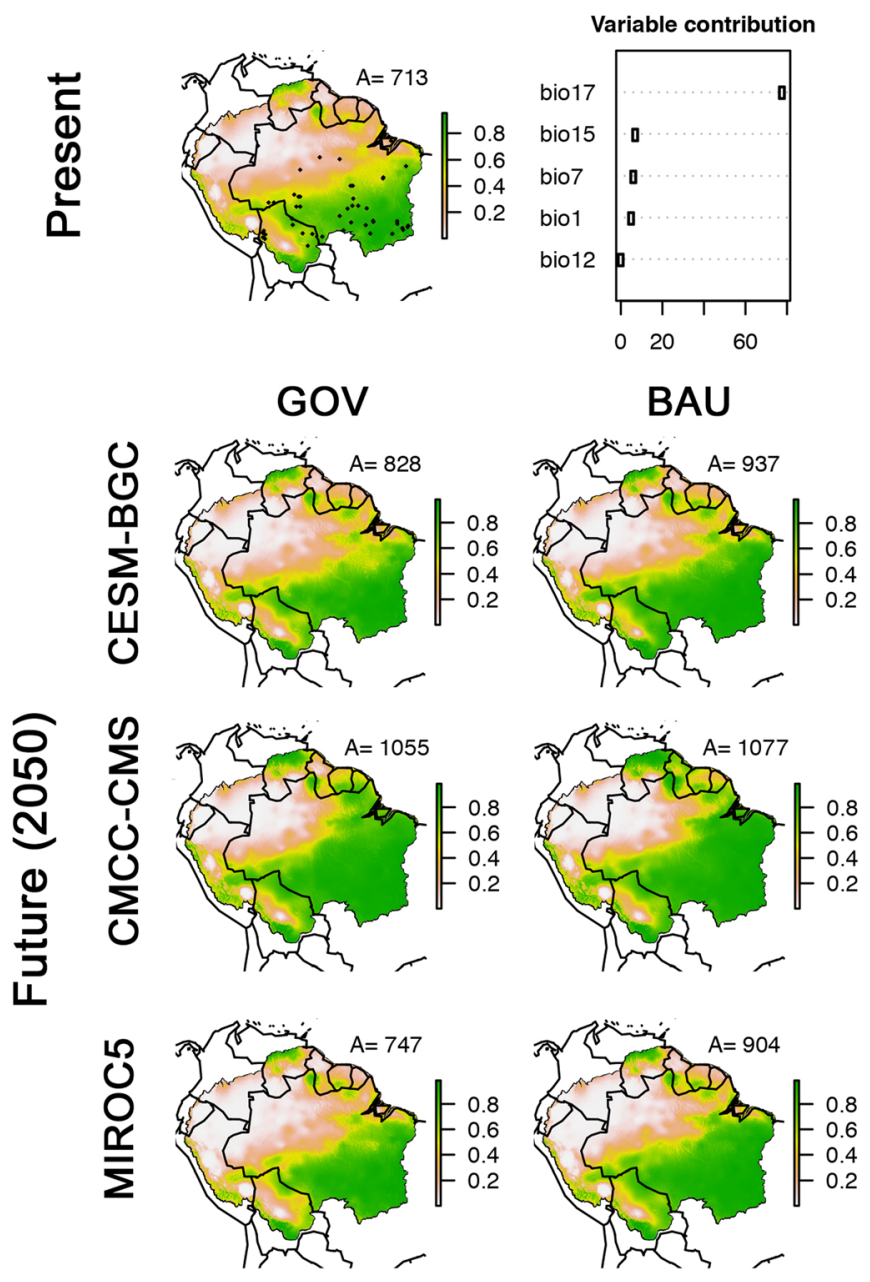

Fig. 6 Predictions of environmentally suitable areas for the occurrence of the liana Machaerium amplum using climate-only models (two first columns) and climate+soil models (two last columns). The first row presents the modelled habitat suitability under current environmental conditions (with black dots indicating species occurrence records), and the scatterplots of the relative contribution of each variable to the models (in \%). For variable

current ones currently inhabit the southern parts of Amazonia, in the Amazonia/Cerrado ecotone (e.g. Nectandra turbacensis and Macherium multifoliolatum). Given that this area is currently drier and more seasonal than core Amazonia, these species are already adapted to the conditions that are predicted to become more common in the basin (Marengo and Espinoza 2016; Betts et al. 2008).

\section{Climate+soil}

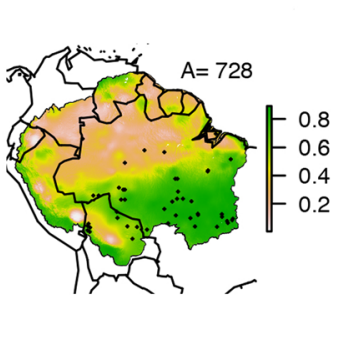

GOV

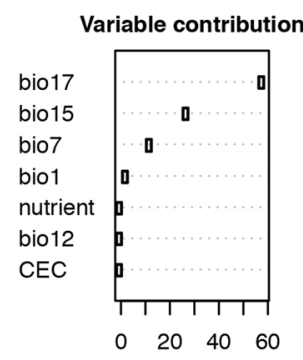

BAU
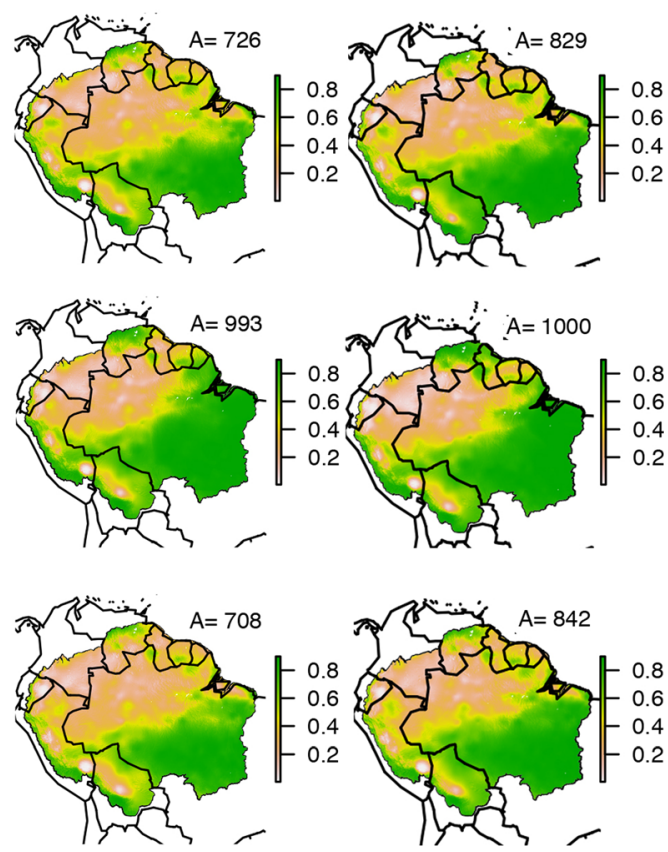

names in full, see Table 1. Future models were based on climatologies developed by three different research groups (CESM1-BGC, CMCC-CMS and MIROC5) taking into account atmospheric $\mathrm{CO}_{2}$ concentration scenarios under governance (GOV) and businessas-usual (BAU) climatic policies. The estimated suitable area (A, in $1000 \mathrm{~km}^{2}$ ) was estimated for each model after applying a threshold on the relative probability values

In general, scenarios assuming future reduction in $\mathrm{CO}_{2}$ emissions predicted larger suitable area for species in 2050 than the business-as-usual emission scenarios. It is worth noting that variation among predicted area using climatic models that assumes the same $\mathrm{CO}_{2}$ emission scenarios but developed by different research groups also occurred. Therefore, uncertainty in the future of Amazonian climate should 
GOV/Current
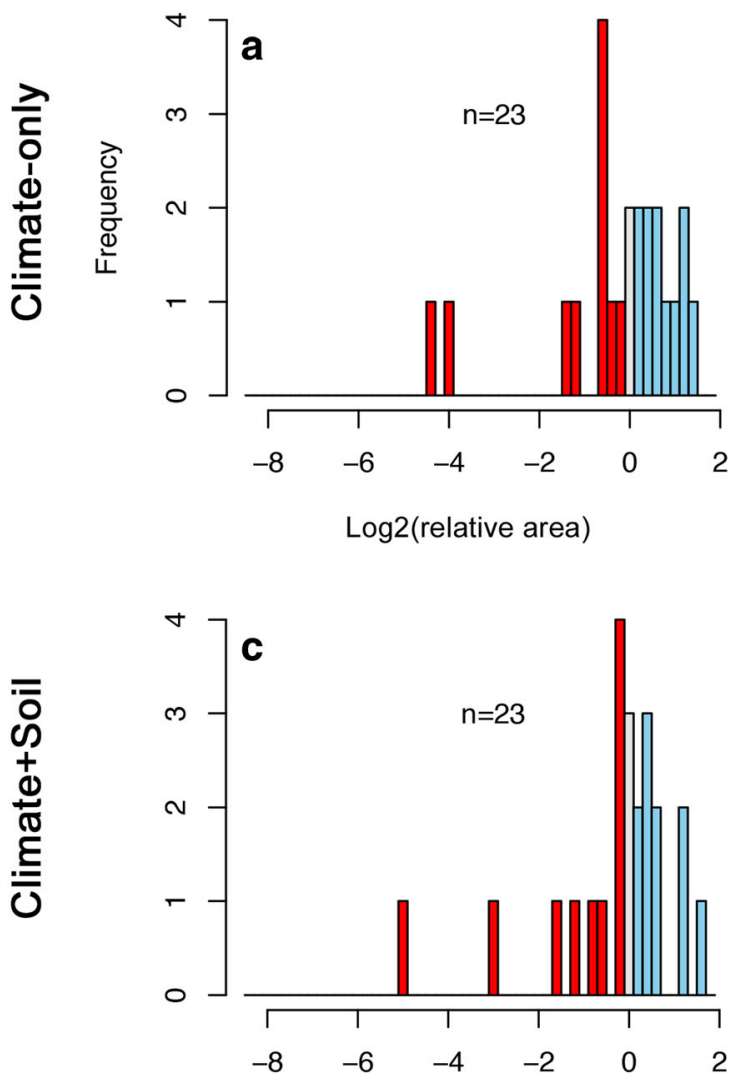

Fig. 7 Frequency histograms of the logarithmically transformed (base 2) ratio between the suitable areas as predicted for each of $n$ plant species in Amazonia under future and current climate conditions for climate-only (a, b) and climate+soil models (c, d). Future climatic conditions presented are based on high-resolution CESM1-BGC climate projections for scenarios of atmospheric $\mathrm{CO}_{2}$ concentrations under (a) and (c) governance (GOV) emission policies; and (b) and (d) business-as-usual (BAU) emission trends.

also be taken into account in predictions of the future of biodiversity and conservation actions.

The evaluation of the future distributions of Amazonian species presented here does not include other potential constraints to species migration towards favourable climates, such as deforestation, land-use change (Feeley et al. 2012; Manchego et al. 2017) or variation in species dispersal abilities (Engler et al. 2009; Willis and Bhagwat 2009). Several taxa may not be able to disperse fast enough to track the changes in suitable areas spatial distribution (Esquivel-Muelbert et al. 2018). This may reduce species ranges by imposing limits to migration. In particular, many shrubs and herbs
BAU/Current
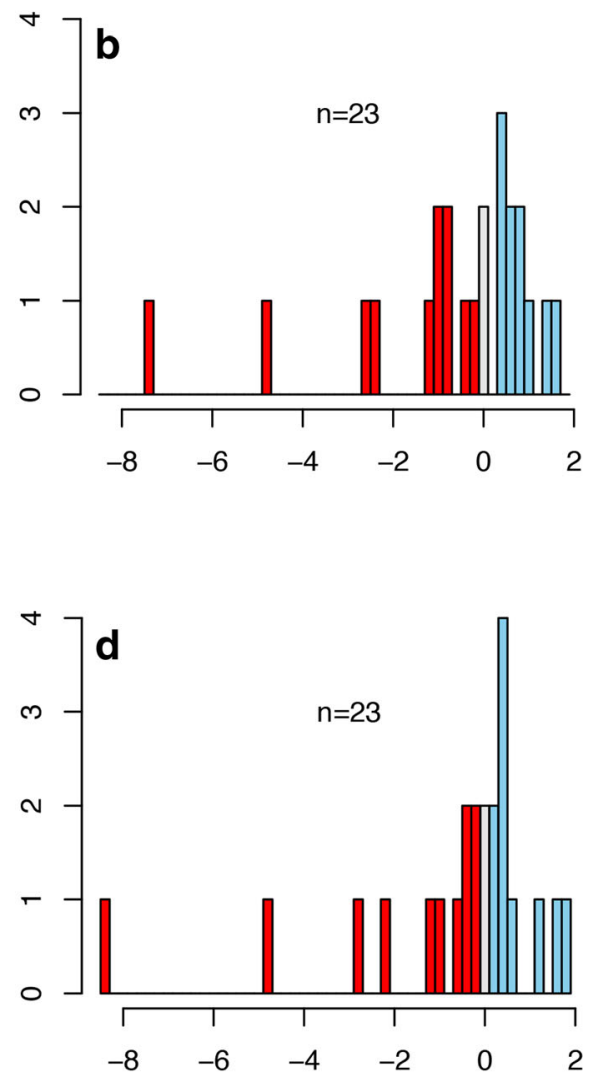

Negative values (red) correspond to species for which the current models predicted larger suitable areas than future models did. Positive values (blue) mean that the future model predicted larger suitable area than the current model for the same species. Henriquezia nitida and Couepia dolichopoda were predicted to have no suitable habitat under future climate conditions, and therefore were not included in the graphs

have limited dispersal ability, so their future distribution areas can be expected to be smaller than the areas providing suitable habitat (Nekola and White 1999; Hubbell 2001). The same is probably true for any plant species whose dispersal is highly dependent on animals with small home ranges. On the other hand, species may have enough acclimation potential to cope with conditions that they do not currently tolerate, but the degree to which this may happen is unknown. Further research is needed to clarify the synergistic effects of soil barriers, land-use change, climate, dispersal ability and potential adaptation on the future of Amazonian species. 


\section{Future: BAU/GOV}

\section{Climate-only}
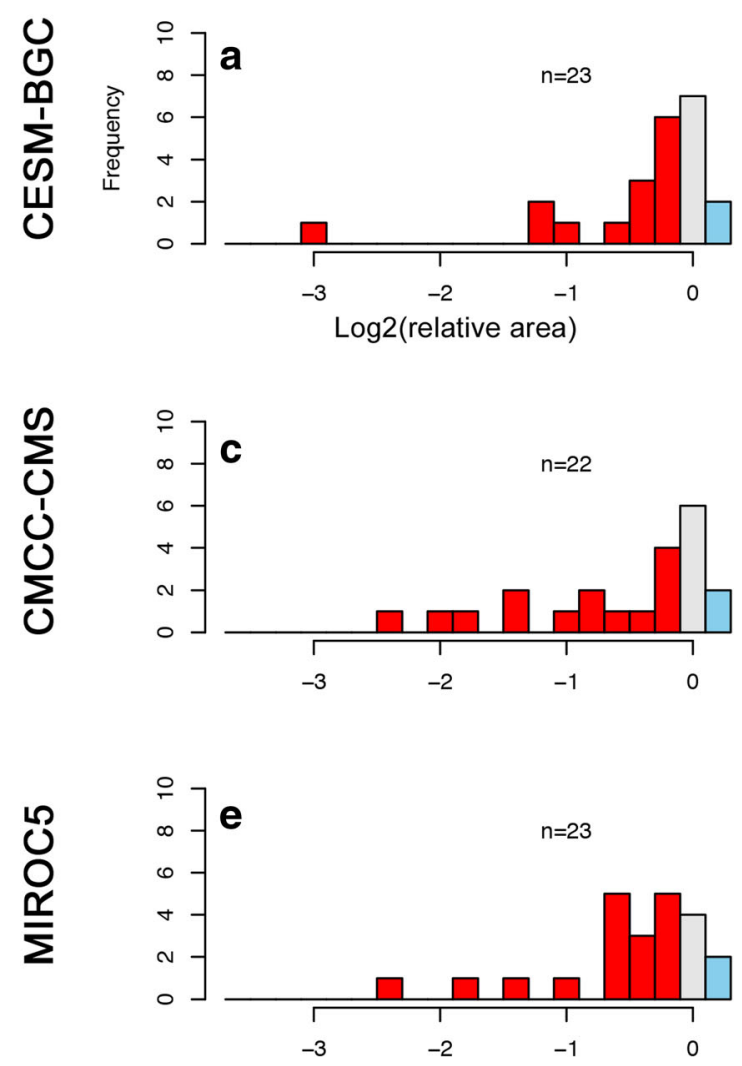

Fig. 8 Frequency histograms of logarithmically transformed (base 2) ratio between suitable area predicted using two scenarios of $\mathrm{CO}_{2}$ concentration peak and decline for $\mathrm{n}$ plant species in Amazonia. Climatic scenarios resulting from governance (GOV) and Business-as-usual (BAU) policies were obtained based on three different climate projections [CESM1-BGC $(\mathbf{a}, \mathbf{b})$, CMCC-CMS (c, d) and MIROC5 (e, f)]. Climate-only species distribution models are shown at left (a, c, e) and climate+soil models at right

\section{Conclusions}

Our results highlight the importance of moving beyond climatic scenarios when modelling biodiversity responses to climate change. Climate-only models are incomplete (Figueiredo et al. 2018; Velazco et al. 2017) and may overestimate future suitability of areas for several species. Species with distributions strongly determined by soil conditions have smaller future suitable areas than climate-only models can predict, especially if the soil conditions to which the species is specialized have limited distribution in
Climate+Soil
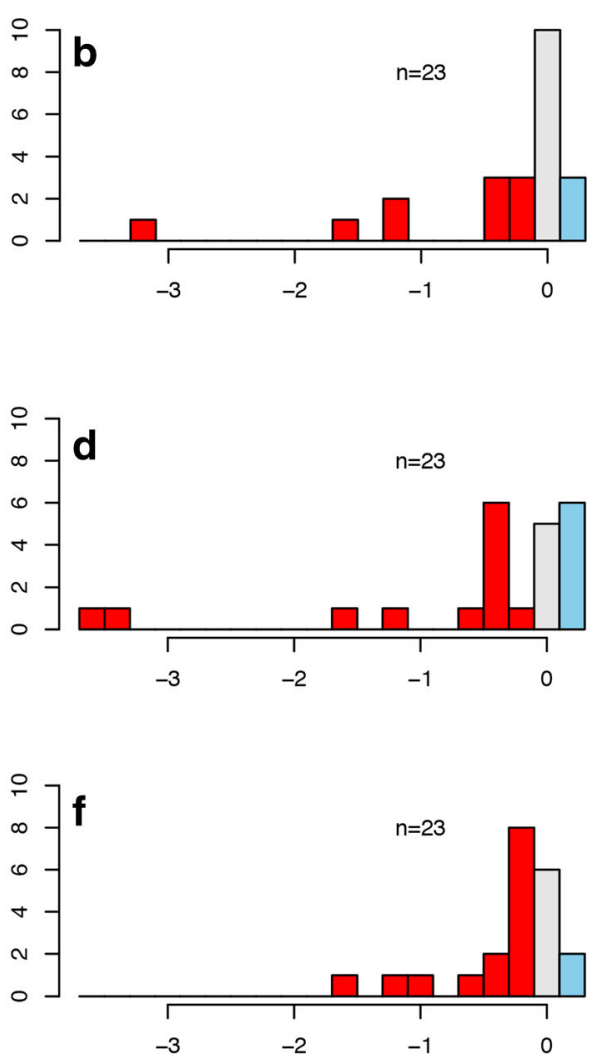

(b, d, f). Negative values (red) correspond to species for which GOV models predicted larger suitable area than BAU models for the same species. Positive values (blue) mean that the BAU future models predicted larger suitable area than the GOV model for the same species. Henriquezia nitida, Couepia dolichopoda and Leopoldinia pulchra were predicted to have no suitable habitat under certain future climate conditions, and were therefore not included in the graphs

Amazonia. These observations are probably true for the larger Amazonian flora, given that strong plant-soil associations have already been described for almost every plant group (Costa et al. 2009; Tuomisto et al. 2016).

Even though our models suggested significant area reduction and even pointed out to possible species extinctions, our results might still be considered optimistic given that rare species or species with small ranges were not included. The conservation status of trees, for instance, is already alarming; many species with small populations 
can be compromised by 2050 (ter Steege et al. 2015). Therefore, estimating species suitable areas on the basis of models that include the main environmental drivers of species distribution is crucial for planning conservation areas that mitigate the effects of climate change on biodiversity. In the predicted more seasonal and hotter future, a large part of the Amazonian flora may not be able to track suitable climates due to soil barriers in between migration pathways. The inclusion of other factors such as dispersal limitation, habitat loss and fragmentation might reveal an even worse scenario. In any case, the future of Amazonian biodiversity is worrisome.

Acknowledgements This study was possible thanks to funding from Academy of Finland (grants to HT), Suomen Kulttuurirahasto (grant to GZ), Brazilian Program for Biodiversity Research, CNPq, Brazilian Ministry of Science and technology, Biological Dynamics of Forest Fragments (BDFFP), Hidroveg Project-FAPEAM/FAPESP and Danish National Research Council. We would like to thank Dirk Karger for insights about future climatologies, and Dr. Henrik Balslev for sharing palm data. We are also thankful for all those who provide freely accessible biological and environmental data.

Author contribution GZ and FF conceived the study. GZ analysed the data with support from HT and FF. GZ and FC led the writing. All authors contributed with data, ideas and writing the manuscript.

Funding Information Open access funding provided by University of Turku (UTU) including Turku University Central Hospital.

Open Access This article is distributed under the terms of the Creative Commons Attribution 4.0 International License (http:// creativecommons.org/licenses/by/4.0/), which permits unrestricted use, distribution, and reproduction in any medium, provided you give appropriate credit to the original author(s) and the source, provide a link to the Creative Commons license, and indicate if changes were made.

Publisher's Note Springer Nature remains neutral with regard to jurisdictional claims in published maps and institutional affiliations

\section{References}

Anderson K, Peters G (2016) The trouble with negative emissions. Science 354:182-183. https://doi.org/10.1126/science. aah4567
Aragão LEOC, Anderson LO, Fonseca MG, Rosan TM, Vedovato LB, Wagner FH, Silva CVJ, Silva Junior CHL, Arai E, Aguiar AP, Barlow J, Berenguer E, Deeter MN, Domingues LG, Gatti L, Gloor M, Malhi Y, Marengo JA, Miller JB, Phillips OL, Saatchi S (2018) 21st century drought-related fires counteract the decline of Amazon deforestation carbon emissions. Nat Commun 9. https://doi.org/10.1038/s41467017-02771-y

Baldeck CA, Tupayachi R, Sinca F, Jaramillo N, Asner GP (2016) Environmental drivers of tree community turnover in western Amazonian forests. Ecography 39:1089-1099. https://doi. org/10.1111/ecog.01575

Bellard C, Bertelsmeier C, Leadley P, Thuiller W, Courchamp F (2012) Impacts of climate change on the future of biodiversity: biodiversity and climate change. Ecol Lett 15:365-377. https://doi.org/10.1111/j.1461-0248.2011.01736.x

Betts RA, Malhi Y, Roberts JT (2008) The future of the Amazon: new perspectives from climate, ecosystem and social sciences. Philos Trans R Soc, B 363:1729-1735. https://doi. org/10.1098/rstb.2008.0011

Bever JD, Dickie IA, Facelli E, Facelli JM, Klironomos J, Moora M, Rillig MC, Stock WD, Tibbett M, Zobel M (2010) Rooting theories of plant community ecology in microbial interactions. Trends Ecol Evol 25:468-478. https://doi. org/10.1016/j.tree.2010.05.004

Boisier JP, Ciais P, Ducharne A, Guimberteau M (2015) Projected strengthening of Amazonian dry season by constrained climate model simulations. Nat Clim Chang 5:656-660. https://doi.org/10.1038/nclimate2658

Buermann W, Saatchi S, Smith TB, Zutta BR, Chaves JA, Milá B, Graham CH (2008) Predicting species distributions across the Amazonian and Andean regions using remote sensing data. J Biogeogr 35:1160-1176. https://doi.org/10.1111 j.1365-2699.2007.01858.x

Bush A, Mokany K, Catullo R, Hoffmann A, Kellermann V, Sgrò C, McEvey S, Ferrier S (2016) Incorporating evolutionary adaptation in species distribution modelling reduces projected vulnerability to climate change. Ecol Lett 19: 1468-1478. https://doi.org/10.1111/ele.12696

Cámara-Leret R, Tuomisto H, Ruokolainen K, Balslev H, Munch Kristiansen S (2017) Modelling responses of western Amazonian palms to soil nutrients. J Ecol 105:367-381. https://doi.org/10.1111/1365-2745.12708

Chamberlain S. (2016). spocc: Interface to Species Occurrence Data Sources. R package version 0.6.0. https:/CRAN.Rproject.org/package=spocc. Accessed 22 June 2018

Costa FRC, Guillaumet J-L, Lima AP, Pereira OS (2009) Gradients within gradients: the mesoscale distribution patterns of palms in a central Amazonian forest. J Veg Sci 20: 69-78. https://doi.org/10.1111/j.1654-1103.2009.05314.x

Cox PM, Pearson D, Booth BB, Friedlingstein P, Huntingford C, Jones CD, Luke CM (2013) Sensitivity of tropical carbon to climate change constrained by carbon dioxide variability. Nature 494:341-344. https://doi.org/10.1038/nature11882

Dijkshoorn K, Huting J, Tempel P (2005) Update of the 1: 5 million Soil and Terrain Database for Latin America and the Caribbean (SOTERLAC; version 2.0). Report 2005/01. ISRIC - world soil information, Wageningen

Dillon ME, Wang G, Huey RB (2010) Global metabolic impacts of recent climate warming. Nature 467:704-706. https://doi. org/10.1038/nature09407 
Emilio T, Quesada CA, Costa FRC, Magnusson WE, Schietti J, Feldpausch TR, Brienen RJW, Baker TR, Chave J, Álvarez E, Araújo A, Bánki O, Castilho CV, Coronado ENH, Killeen TJ, Malhi Y, Mendoza EMO, Monteagudo A, Neill D, Parada GA, Peña-Cruz A, Ramirez-Angulo H, Schwarz M, Silveira M, ter Steege H, Terborgh JW, Thomas R, Torres-Lezama A, Vilanova E, Phillips OL (2014) Soil physical conditions limit palm and tree basal area in Amazonian forests. Plant Ecolog Divers 7:215-229. https://doi.org/10.1080 /17550874.2013.772257

Engler R, Randin CF, Vittoz P, Czáka T, Beniston M, Zimmermann NE, Guisan A (2009) Predicting future distributions of mountain plants under climate change: does dispersal capacity matter? Ecography 32:34-45. https://doi. org/10.1111/j.1600-0587.2009.05789.x

Esquivel-Muelbert A, Baker TR, Dexter KG, Lewis SL, ter Steege H, Lopez-Gonzalez G, Monteagudo Mendoza A, Brienen R, Feldpausch TR, Pitman N, Alonso A, van der Heijden G, Peña-Claros M, Ahuite M, Alexiaides M, Álvarez Dávila E, Murakami AA, Arroyo L, Aulestia M, Balslev H, Barroso J, Boot R, Cano A, Chama Moscoso V, Comiskey JA, Cornejo F, Dallmeier F, Daly DC, Dávila N, Duivenvoorden JF, Duque Montoya AJ, Erwin T, Di Fiore A, Fredericksen T, Fuentes A, García-Villacorta R, Gonzales T, Guevara Andino JE, Honorio Coronado EN, Huamantupa-Chuquimaco I, Killeen TJ, Malhi Y, Mendoza C, Mogollón H, Jørgensen PM, Montero JC, Mostacedo B, Nauray W, Neill D, Vargas PN, Palacios S, Palacios Cuenca W, Pallqui Camacho NC, Peacock J, Phillips JF, Pickavance G, Quesada CA, RamírezAngulo H, Restrepo Z, Reynel Rodriguez C, Paredes MR, Sierra R, Silveira M, Stevenson P, Stropp J, Terborgh J, Tirado M, Toledo M, Torres-Lezama A, Umaña MN, Urrego LE, Vasquez Martinez R, Gamarra LV, Vela CIA, Vilanova Torre E, Vos V, von Hildebrand P, Vriesendorp C, Wang O, Young KR, Zartman CE, Phillips OL (2017a) Seasonal drought limits tree species across the Neotropics. Ecography 40:618-629. https://doi.org/10.1111/ecog.01904

Esquivel-Muelbert A, Galbraith D, Dexter KG, Baker TR, Lewis SL, Meir P, Rowland L, da Costa ACL, Nepstad D, Phillips OL (2017b) Biogeographic distributions of neotropical trees reflect their directly measured drought tolerances. Sci Rep 7: 8334. https://doi.org/10.1038/s41598-017-08105-8

Esquivel-Muelbert A, Baker TR, Dexter KG, Lewis SL, Brienen RJW, Feldpausch TR, Lloyd J, Monteagudo-Mendoza A, Arroyo L, Álvarez-Dávila E, Higuchi N, Marimon BS, Marimon-Junior BH, Silveira M, Vilanova E, Gloor E, Malhi Y, Chave J, Barlow J, Bonal D, Davila Cardozo N, Erwin T, Fauset S, Hérault B, Laurance S, Poorter L, Qie L, Stahl C, Sullivan MJP, ter Steege H, Vos VA, Zuidema PA, Almeida E, Almeida de Oliveira E, Andrade A, Vieira SA, Aragão L, Araujo-Murakami A, Arets E, Aymard CGA, Camargo PB, Barroso JG, Bongers F, Boot R, Camargo JL, Castro W, Chama Moscoso V, Comiskey J, Cornejo Valverde F, Lola da Costa AC, del Aguila Pasquel J, Di Fiore T, Fernanda Duque L, Elias F, Engel J, Flores Llampazo G, Galbraith D, Herrera Fernández R, Honorio Coronado E, Hubau W, Jimenez-Rojas E, Lima AJN, Umetsu RK, Laurance W, Lopez-Gonzalez G, Lovejoy T, Aurelio Melo Cruz O, Morandi PS, Neill D, Núñez Vargas P, Pallqui NC, Parada Gutierrez A, Pardo G, Peacock J, Peña-Claros M, Peñuela-Mora MC, Petronelli P, Pickavance GC, Pitman N,
Prieto A, Quesada C, Ramírez-Angulo H, Réjou-Méchain M, Restrepo Correa Z, Roopsind A, Rudas A, Salomão R, Silva N, Silva Espejo J, Singh J, Stropp J, Terborgh J, Thomas R, Toledo M, Torres-Lezama A, Valenzuela Gamarra L, van de Meer PJ, van der Heijden G, van der Hout P, Vasquez Martinez R, Vela C, Vieira ICG, Phillips OL (2018) Compositional response of Amazon forests to climate change. Glob Chang Biol 0. https://doi.org/10.1111 /gcb.14413

Feeley KJ, Davies SJ, Perez R, Hubbell SP, Foster RB (2011a) Directional changes in the species composition of a tropical forest. Ecology 92:871-882

Feeley KJ, Silman MR, Bush MB, Farfan W, Cabrera KG, Malhi Y, Meir P, Revilla NS, Quisiyupanqui MNR, Saatchi S (2011b) Upslope migration of Andean trees: Andean trees migrate upslope. J Biogeogr 38:783-791. https://doi. org/10.1111/j.1365-2699.2010.02444.x

Feeley KJ, Malhi Y, Zelazowski P, Silman MR (2012) The relative importance of deforestation, precipitation change, and temperature sensitivity in determining the future distributions and diversity of Amazonian plant species. Glob Change Biol 18:2636-2647. https://doi.org/10.1111/j.13652486.2012.02719.x

Figueiredo FOG, Zuquim G, Tuomisto H, Moulatlet GM, Balslev H, Costa FRC (2018) Beyond climate control on species range: the importance of soil data to predict distribution of Amazonian plant species. J Biogeogr 45:190-200. https://doi.org/10.1111/jbi.13104

Fine PVA, Mesones I, Coley PD (2004) Herbivores promote habitat specialization by trees in Amazonian forests. Science 305:663-665. https://doi.org/10.1126 /science.1098982

Gentry AH (1988) Changes in plant community diversity and floristic composition on environmental and geographical gradients. Ann Mo Bot Gard 75:1-34. https://doi.org/10.2307 /2399464

Gruner DS, Bracken MES, Berger SA, Eriksson BK, Gamfeldt L, Matthiessen B, Moorthi S, Sommer U, Hillebrand H (2017) Effects of experimental warming on biodiversity depend on ecosystem type and local species composition. Oikos 126:817. https://doi.org/10.1111/oik.03688

Halvorsen R, Mazzoni S, Dirksen JW, Næsset E, Gobakken T, Ohlson M (2016) How important are choice of model selection method and spatial autocorrelation of presence data for distribution modelling by MaxEnt? Ecol Model 328:108118. https://doi.org/10.1016/j.ecolmodel.2016.02.021

Hengl T, de Jesus JM, Heuvelink GBM, Gonzalez MR, Kilibarda M, Blagotić A, Shangguan W, Wright MN, Geng X, BauerMarschallinger B, Guevara MA, Vargas R, MacMillan RA, Batjes NH, Leenaars JGB, Ribeiro E, Wheeler I, Mantel S, Kempen B (2017) SoilGrids250m: global gridded soil information based on machine learning. PLoS One 12:e169748. https://doi.org/10.1371/journal.pone.0169748

Herraiz AD, Graça PMLA, Fearnside PM (2017) Amazonian flood impacts on managed Brazilnut stands along Brazil's Madeira River: A sustainable forest management system threatened by climate change. For Ecol Manag 406:46-52. https://doi.org/10.1016/j.foreco.2017.09.053

Higgins MA, Ruokolainen K, Tuomisto H, Llerena N, Cardenas G, Phillips OL, Vásquez R, Räsänen M (2011) Geological control of floristic composition in Amazonian forests. J 
Biogeogr 38:2136-2149. https://doi.org/10.1111/j.13652699.2011.02585.x

Higgins MA, Asner GP, Anderson CB, Martin RE, Knapp DE, Tupayachi R, Perez E, Elespuru N, Alonso A (2015) Regional-Scale Drivers of Forest Structure and Function in Northwestern Amazonia. PLoS ONE 10:e0119887

Hijmans R (2016) raster: geographic data analysis and modeling. $\mathrm{R}$ package version 2.5-8. https://CRAN.Rproject. org / package =raster; https://cran.r-project. org/web/packages/raster/index.html. Accessed 22 June 2018

Hijmans RJ, Phillips S, Leathwick J, Elith J (2017) dismo: Species Distribution Modeling. R package version 1.1-4. https://CRAN.R-project.org/package=dismo. Accessed 22 June 2018

Hubbell SP (2001) The unified neutral theory of biodiversity and biogeography. Princeton University Press, Princeton and Oxford

Keeling R, Keeling CD (2017) Atmospheric monthly in situ CO2 data - Mauna Loa Observatory, Hawaii., in: Scripps CO2 program data. UC San Diego Library Digital Collections

Kessler M, Kluge J, Hemp A, Ohlemüller R (2011) A global comparative analysis of elevational species richness patterns of ferns. Glob Ecol Biogeogr 20:868-880. https://doi. org/10.1111/j.1466-8238.2011.00653.x

Knutti R, Masson D, Gettelman A (2013) Climate model genealogy: generation CMIP5 and how we got there: CLIMATE MODEL GENEALOGY. Geophys Res Lett 40:1194-1199. https://doi.org/10.1002/grl.50256

Lenoir J, Svenning J-C (2015) Climate-related range shifts - a global multidimensional synthesis and new research directions. Ecography 38:15-28. https://doi.org/10.1111 /ecog.00967

Levine NM, Zhang K, Longo M, Baccini A, Phillips OL, Lewis SL, Alvarez-Dávila E, de Andrade ACS, Brienen RJW, Erwin TL, Feldpausch TR, Mendoza ALM, Vargas PN, Prieto A, Silva-Espejo JE, Malhi Y, Moorcroft PR (2016) Ecosystem heterogeneity determines the ecological resilience of the Amazon to climate change. PNAS 113:793-797. https://doi.org/10.1073/pnas.1511344112

Levis C, Costa FRC, Bongers F, Peña-Claros M, Clement CR, Junqueira AB, Neves EG, Tamanaha EK, Figueiredo FOG, Salomão RP, Castilho CV, Magnusson WE, Phillips OL, Guevara JE, Sabatier D, Molino J-F, López DC, Mendoza AM, Pitman NCA, Duque A, Vargas PN, Zartman CE, Vasquez R, Andrade A, Camargo JL, Feldpausch TR, Laurance SGW, Laurance WF, Killeen TJ, Nascimento HEM, Montero JC, Mostacedo B, Amaral IL, Vieira ICG, Brienen R, Castellanos H, Terborgh J, de Jesus Veiga Carim M, da Silva Guimarães JR, de Souza Coelho L, de Almeida Matos FD, Wittmann F, Mogollón HF, Damasco G, Dávila N, García-Villacorta R, Coronado ENH, Emilio T, de Andrade Lima Filho D, Schietti J, Souza P, Targhetta N, Comiskey JA, Marimon BS, Marimon B-H, Neill D, Alonso A, Arroyo L, Carvalho FA, de Souza FC, Dallmeier F, Pansonato MP, Duivenvoorden JF, Fine PVA, Stevenson PR, Araujo-Murakami A, C GAA, Baraloto C, do Amaral DD, Engel J, Henkel TW, Maas P, Petronelli P, Revilla JDC, Stropp J, Daly D, Gribel R, Paredes MR, Silveira M, Thomas-Caesar R, Baker TR, da Silva NF, Ferreira LV, Peres CA, Silman MR, Cerón C, Valverde FC, Fiore AD, Jimenez EM, Mora MCP, Toledo M, Barbosa EM, de Matos
Bonates LC, Arboleda NC, de Sousa Farias E, Fuentes A, Guillaumet J-L, Jørgensen PM, Malhi Y, de Andrade Miranda IP, Phillips JF, Prieto A, Rudas A, Ruschel AR, Silva N, von Hildebrand P, Vos VA, Zent EL, Zent S, Cintra BBL, Nascimento MT, Oliveira AA, RamirezAngulo H, Ramos JF, Rivas G, Schöngart J, Sierra R, Tirado M, van der Heijden G, Torre EV, Wang O, Young KR, Baider C, Cano A, Farfan-Rios W, Ferreira C, Hoffman B, Mendoza C, Mesones I, Torres-Lezama A, Medina MNU, van Andel TR, Villarroel D, Zagt R, Alexiades MN, Balslev H, Garcia-Cabrera K, Gonzales T, Hernandez L, Huamantupa-Chuquimaco I, Manzatto AG, Milliken W, Cuenca WP, Pansini S, Pauletto D, Arevalo FR, Reis NFC, Sampaio AF, Giraldo LEU, Sandoval EHV, Gamarra LV, Vela CIA, ter Steege H (2017) Persistent effects of preColumbian plant domestication on Amazonian forest composition. Science 355:925-931. https://doi.org/10.1126 /science.aal0157

Liu C, White M, Newell G (2013) Selecting thresholds for the prediction of species occurrence with presence-only data. $\mathrm{J}$ Biogeogr 40:778-789

Malhi Y, Roberts JT, Betts RA, Killeen TJ, Li W, Nobre CA (2008) Climate change, deforestation, and the fate of the Amazon. Science 319:169-172. https://doi.org/10.1126 /science. 1146961

Manchego CE, Hildebrandt P, Cueva J, Espinosa CI, Stimm B, Günter S (2017) Climate change versus deforestation: implications for tree species distribution in the dry forests of southern Ecuador. PLoS One 12:e0190092. https://doi. org/10.1371/journal.pone.0190092

Marengo JA, Espinoza JC (2016) Extreme seasonal droughts and floods in Amazonia: causes, trends and impacts. Int J Climatol 36:1033-1050. https://doi.org/10.1002/joc.4420

McMichael CH, Palace MW, Golightly M (2014) Bamboodominated forests and pre-Columbian earthwork formations in South-Western Amazonia. J Biogeogr 41:1733-1745. https://doi.org/10.1111/jbi.12325

Merow C, Smith MJ, Silander JA (2013) A practical guide to MaxEnt for modeling species' distributions: what it does, and why inputs and settings matter. Ecography 36:1058-1069. https://doi.org/10.1111/j.1600-0587.2013.07872.x

Miles L, Grainger A, Phillips O (2004) The impact of global climate change on tropical forest biodiversity in Amazonia. Glob Ecol Biogeogr 13:553-565. https://doi.org/10.1111 /j.1466-822X.2004.00105.x

Moss RH, Edmonds JA, Hibbard KA, Manning MR, Rose SK, van Vuuren DP, Carter TR, Emori S, Kainuma M, Kram T, Meehl GA, Mitchell JFB, Nakicenovic N, Riahi K, Smith SJ, Stouffer RJ, Thomson AM, Weyant JP, Wilbanks TJ (2010) The next generation of scenarios for climate change research and assessment. Nature 463:747-756. https://doi. org/10.1038/nature08823

Moulatlet GM, Zuquim G, Figueiredo FOG, Lehtonen S, Emilio T, Ruokolainen K, Tuomisto H (2017) Using digital soil maps to infer edaphic affinities of plant species in Amazonia: problems and prospects. Ecol Evol 7:84638477. https://doi.org/10.1002/ece3.3242

Muscarella R, Galante PJ, Soley-Guardia M, Boria RA, Kass J, Uriarte M, Anderson RP (2014) ENMeval: An R package for conducting spatially independent evaluations and estimating 
optimal model complexity for ecological niche models. Methods Ecol Evol 5:1198-1205

Muscarella R, Galante PJ, Soley-Guardia M, Boria RA, Kass JM, Uriarte M, Anderson RP (2017) ENMeval: Automated runs and evaluations of Ecological Niche Models. R package Version 0.2.2. https://cran.r-project. org/web/packages/ENMeval/index.html. Accessed 22 June 2018

Nachtergaele F, van Velthuizen H, Verelst L, Wiberg D (2012) Harmonized World Soil Database version 1.2

Nekola JC, White PS (1999) The distance decay of similarity in biogeography and ecology. J Biogeogr 26:867-878. https://doi.org/10.1046/j.1365-2699.1999.00305.x

Nepstad DC, Tohver IM, Ray D, Moutinho P, Cardinot G (2007) Mortality of large trees and lianas following experimental drought in an Amazon Forest. Ecology 88:2259-2269. https://doi.org/10.1890/06-1046.1

Parmesan C, Yohe G (2003) A globally coherent fingerprint of climate change impacts across natural systems. Nature 421: 37-42. https://doi.org/10.1038/nature01286

Pecl GT, Araújo MB, Bell JD, Blanchard J, Bonebrake TC, Chen I-C, Clark TD, Colwell RK, Danielsen F, Evengård B, Falconi L, Ferrier S, Frusher S, Garcia RA, Griffis RB, Hobday AJ, Janion-Scheepers C, Jarzyna MA, Jennings S, Lenoir J, Linnetved HI, Martin VY, McCormack PC, McDonald J, Mitchell NJ, Mustonen T, Pandolfi JM, Pettorelli N, Popova E, Robinson SA, Scheffers BR, Shaw JD, Sorte CJB, Strugnell JM, Sunday JM, Tuanmu M-N, Vergés A, Villanueva C, Wernberg T, Wapstra E, Williams SE (2017) Biodiversity redistribution under climate change: impacts on ecosystems and human well-being. Science 355 : eaai9214. https://doi.org/10.1126/science.aai9214

Poloczanska ES, Brown CJ, Sydeman WJ, Kiessling W, Schoeman DS, Moore PJ, Brander K, Bruno JF, Buckley LB, Burrows MT, Duarte CM, Halpern BS, Holding J, Kappel CV, O'Connor MI, Pandolfi JM, Parmesan C, Schwing F, Thompson SA, Richardson AJ (2013) Global imprint of climate change on marine life. Nat Clim Chang 3:919

Poorter L, van der Sande MT, Thompson J, Arets EJMM, Alarcón A, Álvarez-Sánchez J, Ascarrunz N, Balvanera P, BarajasGuzmán G, Boit A, Bongers F, Carvalho FA, Casanoves F, Cornejo-Tenorio G, Costa FRC, de Castilho CV, Duivenvoorden JF, Dutrieux LP, Enquist BJ, FernándezMéndez F, Finegan B, Gormley LHL, Healey JR, Hoosbeek MR, Ibarra-Manríquez G, Junqueira AB, Levis C, Licona JC, Lisboa LS, Magnusson WE, MartínezRamos M, Martínez-Yrizar A, Martorano LG, Maskell LC, Mazzei L, Meave JA, Mora F, Muñoz R, Nytch C, Pansonato MP, Parr TW, Paz H, Pérez-García EA, Rentería LY, Rodríguez-Velazquez J, Rozendaal DMA, Ruschel AR, Sakschewski B, Salgado-Negret B, Schietti J, Simões M, Sinclair FL, Souza PF, Souza FC, Stropp J, ter Steege H, Swenson NG, Thonicke K, Toledo M, Uriarte M, van der Hout P, Walker P, Zamora N, Peña-Claros M (2015) Diversity enhances carbon storage in tropical forests. Glob Ecol Biogeogr 24:1314-1328. https://doi.org/10.1111 /geb.12364

Quesada CA, Lloyd J, Schwarz M, Patiño S, Baker TR, Czimczik C, Fyllas NM, Martinelli L, Nardoto GB, Schmerler J, Santos AJB, Hodnett MG, Herrera R, Luizão FJ, Arneth A, Lloyd G,
Dezzeo N, Hilke I, Kuhlmann I, Raessler M, Brand WA, Geilmann H, Moraes Filho JO, Carvalho FP, Araujo Filho RN, Chaves JE, Cruz Junior OF, Pimentel TP, Paiva R (2010) Variations in chemical and physical properties of Amazon forest soils in relation to their genesis. Biogeosciences 7: 1515-1541. https://doi.org/10.5194/bg-7-1515-2010

Quesada CA, Lloyd J, Anderson LO, Fyllas NM, Schwarz M, Czimczik CI (2011) Soils of Amazonia with particular reference to the RAINFOR sites. Biogeosciences 8:1415-1440. https://doi.org/10.5194/bg-8-1415-2011

Quesada CA, Phillips OL, Schwarz M, Czimczik CI, Baker TR, Patiño S, Fyllas NM, Hodnett MG, Herrera R, Almeida S, et al (2012) Basin-wide variations in Amazon forest structure and function are mediated by both soils and climate. Biogeosciences 9:2203-2246

Riahi K, Rao S, Krey V, Cho C, Chirkov V, Fischer G, Kindermann G, Nakicenovic N, Rafaj P (2011) RCP 8.5A scenario of comparatively high greenhouse gas emissions. Clim Chang 109:33-57. https://doi.org/10.1007/s10584-0110149-y

Robertson M (2016) biogeo: point data quality assessment and coordinate conversion. R package version 1.0. https://CRAN. R-project.org/package=biogeo. Accessed 22 June 2018

Saatchi SS, Houghton RA, Dos Santos Alvalá RC, Soares JV, Yu Y (2007) Distribution of aboveground live biomass in the Amazon basin. Glob Chang Biol 13:816-837. https://doi. org/10.1111/j.1365-2486.2007.01323.x

Schietti J, Emilio T, Rennó CD, Drucker DP, Costa FRC, Nogueira A, Baccaro FB, Figueiredo F, Castilho CV, Kinupp V, Guillaumet J-L, Garcia ARM, Lima AP, Magnusson WE (2014) Vertical distance from drainage drives floristic composition changes in an Amazonian rainforest. Plant Ecolog Divers 7:241-253. https://doi.org/10.1080 $/ 17550874.2013 .783642$

Sillmann J, Kharin VV, Zwiers FW, Zhang X, Bronaugh D (2013) Climate extremes indices in the CMIP5 multimodel ensemble: part 2. Future climate projections: CMIP5 PROJECTIONS OF EXTREMES INDICES. J Geophys Res-Atmos 118:2473-2493. https://doi.org/10.1002 /jgrd.50188

Spracklen DV, Arnold SR, Taylor CM (2012) Observations of increased tropical rainfall preceded by air passage over forests. Nature 489:282-285. https://doi.org/10.1038 /nature 11390

Syfert MM, Smith MJ, Coomes DA (2013) The effects of sampling Bias and model complexity on the predictive performance of MaxEnt species distribution models. PLoS One 8: e55158. https://doi.org/10.1371/journal.pone.0055158

ter Steege H, Pitman NCA, Killeen TJ, Laurance WF, Peres CA, Guevara JE, Salomão RP, Castilho CV, Amaral IL, de Almeida Matos FD, de Souza Coelho L, Magnusson WE, Phillips OL, de Andrade Lima Filho D, de Jesus Veiga Carim M, Irume MV, Martins MP, Molino J-F, Sabatier D, Wittmann F, López DC, da Silva Guimaraes JR, Mendoza AM, Vargas PN, Manzatto AG, Reis NFC, Terborgh J, Casula KR, Montero JC, Feldpausch TR, Coronado ENH, Montoya AJD, Zartman CE, Mostacedo B, Vasquez R, Assis RL, Medeiros MB, Simon MF, Andrade A, Camargo JL, Laurance SGW, Nascimento HEM, Marimon BS, Marimon B-H, Costa F, Targhetta N, Vieira ICG, Brienen R, Castellanos H, Duivenvoorden JF, Mogollón HF, Piedade 
MTF, C GAA, Comiskey JA, Damasco G, Dávila N, GarcíaVillacorta R, Diaz PRS, Vincentini A, Emilio T, Levis C, Schietti J, Souza P, Alonso A, Dallmeier F, Ferreira LV, Neill D, Araujo-Murakami A, Arroyo L, Carvalho FA, Souza FC, do Amaral DD, Gribel R, Luize BG, Pansonato MP, Venticinque E, Fine P, Toledo M, Baraloto C, Cerón C, Engel J, Henkel TW, Jimenez EM, Maas P, Mora MCP, Petronelli P, Revilla JDC, Silveira M, Stropp J, ThomasCaesar R, Baker TR, Daly D, Paredes MR, da Silva NF, Fuentes A, Jørgensen PM, Schöngart J, Silman MR, Arboleda NC, Cintra BBL, Valverde FC, Fiore AD, Phillips JF, van Andel TR, von Hildebrand P, Barbosa EM, de Matos Bonates LC, de Castro D, de Sousa Farias E, Gonzales T, Guillaumet J-L, Hoffman B, Malhi Y, de Andrade Miranda IP, Prieto A, Rudas A, Ruschell AR, Silva N, Vela CIA, Vos VA, Zent EL, Zent S, Cano A, Nascimento MT, Oliveira AA, Ramirez-Angulo H, Ramos JF, Sierra R, Tirado M, Medina MNU, van der Heijden G, Torre EV, Vriesendorp C, Wang O, Young KR, Baider C, Balslev H, de Castro N, Farfan-Rios W, Ferreira C, Mendoza C, Mesones I, Torres-Lezama A, Giraldo LEU, Villarroel D, Zagt R, Alexiades MN, GarciaCabrera K, Hernandez L, Huamantupa-Chuquimaco I, Milliken W, Cuenca WP, Pansini S, Pauletto D, Arevalo FR, Sampaio AF, Sandoval EHV, Gamarra LV (2015) Estimating the global conservation status of more than 15 , 000 Amazonian tree species. Sci Adv 1:e1500936. https://doi.org/10.1126/sciadv.1500936

Thomas CD, Cameron A, Green RE, Bakkenes M, Beaumont LJ, Collingham YC, Erasmus BFN (2004) Extinction risk from climate change 427,4

Thomson AM, Calvin KV, Smith SJ, Kyle GP, Volke A, Patel P, Delgado-Arias S, Bond-Lamberty B, Wise MA, Clarke LE, Edmonds JA (2011) RCP4.5: a pathway for stabilization of radiative forcing by 2100 . Clim Chang 109:77-94. https://doi.org/10.1007/s10584-011-0151-4

Tuomisto H, Poulsen AD (1996) Influence of edaphic specialization on pteridophyte distribution in neotropical rain forests. $\mathrm{J}$ Biogeogr 23:283-293. https://doi.org/10.1046/j.13652699.1996.00044.x

Tuomisto H, Ruokolainen K, Aguilar M, Sarmiento A (2003) Floristic patterns along a $43-\mathrm{km}$ long transect in an Amazonian rain forest. J Ecol 91:743-756. https://doi. org/10.1046/j.1365-2745.2003.00802.x

Tuomisto H, Zuquim G, Cárdenas G (2014) Species richness and diversity along edaphic and climatic gradients in Amazonia. Ecography 37:1034-1046. https://doi.org/10.1111 /ecog.00770

Tuomisto H, Moulatlet GM, Balslev H, Emilio T, Figueiredo FOG, Pedersen D, Ruokolainen K (2016) A compositional turnover zone of biogeographical magnitude within lowland Amazonia. J Biogeogr 43:2400-2411. https://doi. org/10.1111/jbi.12864

van Vuuren DP, Edmonds J, Kainuma M, Riahi K, Thomson A, Hibbard K, Hurtt GC, Kram T, Krey V, Lamarque J-F, Masui T, Meinshausen M, Nakicenovic N, Smith SJ, Rose SK (2011a) The representative concentration pathways: an overview. Clim Chang 109:5-31. https://doi.org/10.1007/s10584011-0148-Z

van Vuuren DP, Stehfest E, den Elzen MGJ, Kram T, van Vliet J, Deetman S, Isaac M, Klein Goldewijk K, Hof A, Mendoza Beltran A, Oostenrijk R, van Ruijven B (2011b) RCP2.6: exploring the possibility to keep global mean temperature increase below $2^{\circ} \mathrm{C}$. Clim Chang 109:95-116. https://doi. org/10.1007/s10584-011-0152-3

Velazco SJE, Galvão F, Villalobos F, Júnior PDM (2017) Using worldwide edaphic data to model plant species niches: an assessment at a continental extent. PLoS One 12:e186025. https://doi.org/10.1371/journal.pone.0186025

Walther G-R, Post E, Convey P, Menzel A, Parmesan C, Beebee TJC, Fromentin J-M, Hoegh-Guldberg O, Bairlein F (2002) Ecological responses to recent climate change. Nature 416: 389-395. https://doi.org/10.1038/416389a

Warren DL, Wright AN, Seifert SN, Shaffer HB (2014) Incorporating model complexity and spatial sampling bias into ecological niche models of climate change risks faced by 90 California vertebrate species of concern. Divers Distrib 20:334-343. https://doi.org/10.1111/ddi.12160

Willis KJ, Bhagwat SA (2009) Biodiversity and climate change. Science 326:806-807. https://doi.org/10.1126 /science. 1178838

Zuquim G (2017) Soil exchangeable cation concentration map of the Amazonian, link to GeoTif. https://doi.org/10.1594 /PANGAEA.879542

Zuquim G, Tuomisto H, Costa FRC, Prado J, Magnusson WE, Pimentel T, Braga-Neto R, Figueiredo FOG (2012) Broad scale distribution of ferns and lycophytes along environmental gradients in central and northern Amazonia, Brazil. Biotropica 44:752-762. https://doi.org/10.1111/j.17447429.2012.00880.x

Zuquim G, Tuomisto H, Jones MM, Prado J, Figueiredo FOG, Moulatlet GM, Costa FRC, Quesada CA, Emilio T (2014) Predicting environmental gradients with fern species composition in Brazilian Amazonia. J Veg Sci 25:1195-1207. https://doi.org/10.1111/jvs. 12174

Zuquim G, Moulatlet GM, Quesada CA, Tuomisto H (2017) Persistent effects of soils on Amazonian forest composition 